\title{
COMPOSIÇÃO BOTÂNICA DA FORRAGEM DISPONIVEL E SELECIONADA POR NOVILHOS FISTULADOS NO ESÔFAGO EM PASTAGEM TROPICAL MISTA
}

ORLANDO MONTEIRO DE CARVALHO FILHO

Orientador: MOACYR CORSI

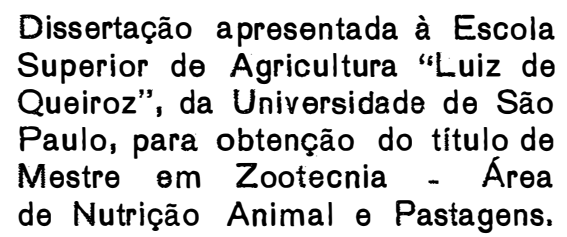

P I R A C I A B A

Estado de São Paulo - Brasil

Junho -1980 


\section{Aos meus pais \\ Orlando e Maria Augusta \\ minha gratidão;}
Aos meus irmãos
Antônio e Licia
pelo anoio e estimulo;
A minha esposa Evany
e meus filhos Luciana e Camilo
pela compreensão, sacrifício e amor


Ao Prof. Dr. Moacyr Corsi, pela orientação e amizade constantes.

Ao Dr. Antonio 0liveira Lobão, pela fistulação e assistēncia pōs-opera tōria aos animais experimentais, alēm do valioso treinamento no mane jo dos mesmos.

Ao colega Engo Agrōnomo Ari Pinheiro Camarão, pela co-participação res ponsāve? e prestimosa na condução do experimento.

$\bar{A}$ Empresa Brasileira de Pesquisa Agropecuāria (EMBRAPA), pela oportuni dade de realização do Curso de Mestrado, em particular à Direção do Centro de Pesquisa Agronecuäria do Tröpico Semi-Arido (CPATSA), que tambēm possibilitou a conclusão desta dissertação.

Ao Instituto de Zootecnia da Secretaria de Agricultura do Estado de São Paulo, pela cessão dos animais, permitindo a realizacão deste trabaTho.

Ao Prof. Dr. Celso Lemaire de Moraes, pelas facilidades concedidas na execução de trabalhos de laboratōrio.

Ao Prof. Dr. Irineu Umberto Packer, pela orientação no delineamento ex perimental.

Ao colena Médico-Veterinārio Santiago Farinas Jorge, pela colaboração na fistulac̃a e assistencia pōs-operatōria acs animais.

Ao colega do CPATSA, Estatístico Carlos Alberto Vasconcelos de 01 ivej ra, pela colaboraçõo nas anāi ises eștatísticas.

Ao colega José Crisóstomo de Oliveira, pela ajuda na fase inicial dos trabalhos. 
Aos Professores do Curso de Nutrição Animal e Pastagens da ESALQ, pelos conhecimentos adquiridos.

Aos funcionārios do Departamento de Zootecnia desta Escola, em particu lar ao Sr. Antōnio Sabino, pelo inestimāvel auxîlio nas tarefas de campo.

Aos colegas do Curso de Pōs-Graduação, pela convivēncia profícua.

$\bar{A}$ todos aqueles que direta e indiretamente colaboraram na realização deste trabalho. 
I N D I C E

păgina

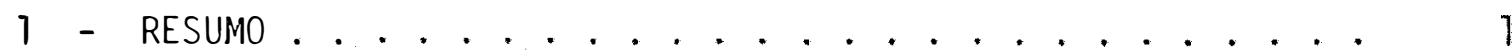

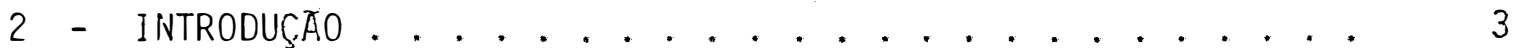

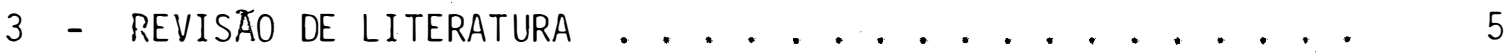

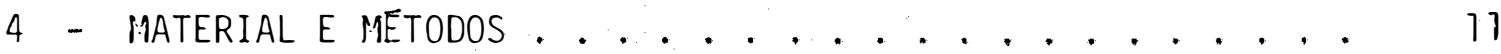

4.1 - Período e Area Experimental . . . . . . . . . 11

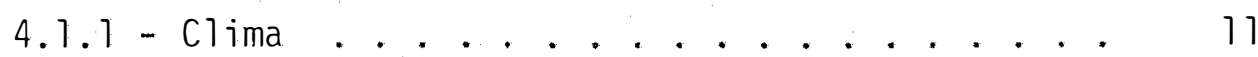

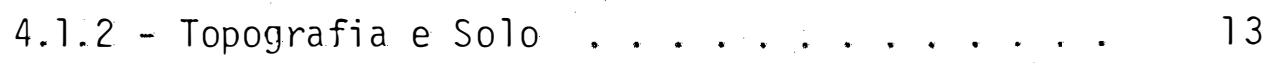

4.1 .3 - Manejo da Pastagem ........... 14

4.2 - Animais Experimentais ........... 15

4.3 - Amostragens . . . . . . . . . . . . 16

4.3.1 - Composição Botānica da Forragem Ingerida . . 16

4.3.1.1 - Separação Botānica das Amostras . 20

4.3.2 - Composição Botānica da Forragem Disponível . 21

4.3.3 - Seletividade de Pastejo . . . . . . 22

4.4 - Anālises Estatísticas . . . . . . . . . . 22

5 - RESUltAdOS E discusSAO . . . . . . . . . . . 24

5.1 - Forragem Disponível . . . . . . . . . . . . 24

5.2 - Composição Botānica da Dieta e Seletividade . . . . 26

5.2.1 - Calibração do Método de Separação Botānica do Material Ingerido . . . . . . . . 39

5.3 - Comportamento dos Animais Fistulados . . . . . . . . 40

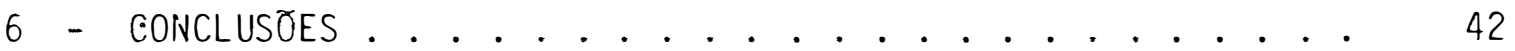


v .

Pägina

7 - SUMMARY . . . . . . . . . . . . . . . . . . . . .

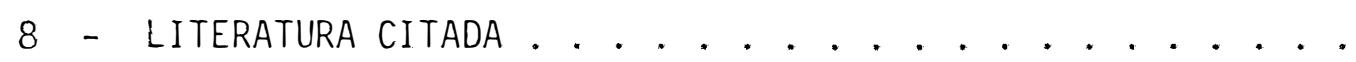

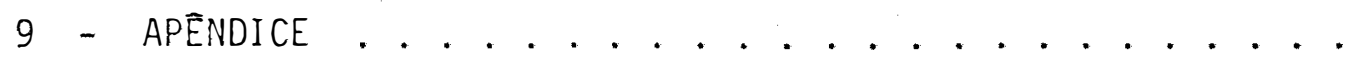




\section{RESUMO}

Com o objetivo de investigar a seletividade de pastejo, considerando como hipōtese o fato de que a estacionalidade desse comportamento constitui fator de extrema importáncia para persisténcia de legumino sas tropicais associadas a gramíneas tropicais, foi estudada, em pastagem tropical mista, a composição botānica da forragem disponivel - em sete épo cas de janeiro-novembro/79 - e da forragem selecionada por novilhos fistulados no esōfago - em seis ēpocas de março-novembro/79.

Essa pastacem, pertencente ao Departamento de Zootecnia da ESALQ, no Estado de São Paulo, era constituĩda de capim Colonião (Panicum maximum), Soja Perene (Glycine wightii), grama Batatais (Paspalum notatum) e outras gramineas, cujas participações, em termos de peso seco da forra gem verde disponível, variaram de 54 a $80 \%, 25$ a $9 \%, 14$ a $6 \%$ e 6 a $9 \%$, res pectivamente, ao longo do perīodo experimental.

Para avaliação dessa disponibilidade e sua composição botā-

nica, foram cortados, em cada amostragem, 20 quadrados de $1 \mathrm{~m} \times 1 \mathrm{~m}$, de igual nümero de parcelas fixas na pastagem.

A forrangem disponível sofreu variações estacionais, sobretu do o material vegetativo, cujos componentes responderam diferentemente aos efeitos do clima e do pastejo. A ocorréncia de geadas, em meio ao período experimental, agravou substancialmente as quedas de disponibilidade desses componentes no inverno, notadamente da Soja Perene. Inversamente, o materi al morto chenou a atingir mais da metade da MS presente no pasto nessa época. Os efeitos associados do clima, ataque de pragas e da pressão de paste 
jo, particularmente daquela imprimida no início da fase de rebrota da pastagem (primavera), levou a uma menor oferta e participação da Soja na forragem disponível ao final do estudo.

A composição botānica da dieta foi estimada por separação manual, com o auxîlio de lupas binoculares, a partir de amostras obtidas por 5 novilhos fistulados no esófago, em pastejo de 30-40 minutos, por 4 dias consecutivos, em cada amostragem.

Em março e abril, quando houve maior oferta de forragem ver de, os animais puderam selecionar suas dietas, manifestando rejeição pela Soja Perene. Nas épocas posteriores essa seletividade foi restringida pela baixa disponibilidade de forragem verde no inverno, acentuada pela maior pressão de pastejo na primavera. O consumo relativo da Soja, inicialmente constante, apresentou uma tendéncia linear crescente a partir de maio,quando se acentuou o declīnio da forragem verde disponível por unidade ani mal. Sua aceitabilidade melhorou proģressivamente com a diminuição da disponibilidade desse material para os animais.

o Colonião foi selecionado apenas em: março. Nas demais épocas, provave?mente pela progressiva remoçãa de sua porção folhosa, o consu mo relativo desse componente não diferiu de suas proporções na pastagem. De outro lado, a grama Batatais demonstrou ser mais palatāivel na fase de rebrota, chegando a contribuir, em abri1, com 16\% da forragem verde ingeri da. O componente Outras Gramineas teve maior participação na dieta durante o inverno.

Hơve diferenças entre animais na composição botānica da dieta, norēm não houve variação entre dias de amostragem. A interação anima 1 X épocas foi consistente. 0 desempenho animal, comparável ao de animais não fistulados, evidenciou a viabilidade de uso de bovinos com fístulas esofágicas para ensaios de pastejo.

Não obstante os fatores atîpicos (geadas e pragas), que con dicionaram parte das respostas obtidas neste trabalho, é possivel sugerir que o equilíbrio botánico de uma pastagem tropical mista pode ser prejudicado quando, em seu manejo, a seletjvidade de pastejo é restringida, sobretudo na fase inicial da estaçãn de crescimento. 
2. INTRODUÇÃO

A produção animal, sob condições de pastejo, ē o resultado final de uma sērie complexa de interações entre o animal e o pasto. 0 estabelecimento de alternativas de manejo a esse sistema depende, portanto, do conhecimento de seus parāmetros indicadores básicos e de suas interrelações.

Pastagens mistas de graminea/leguminosa tem sido amplamente consideradas como forma eficiente e económica de disponibilidade conti nua de forragem de boa qualidade, para a produção animal. 0 valor proeminente dessa associação fundamenta-se na capacidade da leguminosa de man ter constante seu teor de nitrogênio - obtido por fixação simbiōtica do $\mathrm{N}_{2}$ atmosfërico - o que não ocorre com pastos de gramīneas exclusivas, fer tilizadas ou não com $N$, cujo teor desse nutriente oscila grandemente, podendo cair, inclusive, abaixo dos requisitos de mantença dos animais, a despeito de grandes quantidades de forragem produzidas (NORRIS, 1972). Ademais, o aumento da participação da leguminosa na dieta melhora sua qualidade, pela maior eficiēncia de utilização da gramînea e aumento do consumo de energia digestível pelo animal (MINSON e MILFORD, 1967).

Por outro lado, a maior eficiēncia fotossintética das gramíneas tropicais - plantas de ciclo $C_{4}$ - com consequente potencial de pro dutividade superior ao das leguminosas tropicais, de ciclo $C_{3}$, as torna ecologicamente mais bem sucedidas, quando em associação (LUDLOW e WILSON, 1970 e 1971). Em razão disso, o manejo adequado a essas pastagens deve vi 
sar a manutenção da produtividade da leguminosa, tendo-se em conta, a lēm de outros fatores,o estabelecimento de uma simbiose efetiva; a provisão de uma nutrição mineral adequada, com vistas ao bom funcionamento dessa simbiose e crescimento da planta, e a imposição de um regime de pastejo que permita à leguminosa persistir, contribuindo com nitrogēnio (NORRIS, 1972).

Abstraindo-se os demais fatores, è bastante conhecidó que diferenças na palatabilidade das espécies, em pastagens mistas, levam ao pastejo seletivo, de extrema importāncia para a produtividade e persistén cia dessas pastagens (STOBBS, 1977). As evidências indicam que, em geral, as graminneas tropicais são altamente preferidas às leguminosas tropicais, durante as estações de primavera e verão (STOBBS, 1975).

Animais fistulados no esōfago tem sido extensivamente utilizados, nas ūltimas décadas, na availiação da composição botānica e quîmi ca da forragem selecionada, em condições de pastejo (ALDER, 1969).

Em condições de pastagens nativas do cerrado brasileiro, foi tambēm evidenciada a seletividade de pastejo na composição botánica e quîmica da dieta de bovinos, e a viabilidade da utilização de novilhos fistulados no esōfago, em ensaios de pastejo (SIMAO NETO, 1976).

Um estudo dessa natureza, que propicie a obtenção de infor mações sobre alguns parāmetros do relacionamento animal/pasto, particula $\underline{r}$ mente em se tratando de pastagens mistas de graminea/leguminosa, torna-se relevante e justificāvel, quando se constata a inexistência de investigações similares em nossas condições, capazes de prover subsídios para o es tabelecimento de alternativas de manejo adequadas. 


\section{REVISAO DE LITERATURA}

A seletividade de pastejo por bovinos e ovinos tem sido extensivamente demonstrada por inümeros pesquisadores, trabalhando mais diversos tipos de pastagens do mundo.

Especificamente à nastagens cultivadas de gramīnea/legumi nosa tropicais, como jā mencionado anteriormente, a seletividade de pastejo constitui-se em um importante fator de persistēncia da leguminosa e conse quente manutenção da produtividade da nastagem como um todo (STOBBS, 1977), tendo em vista que nos períodos de primavera e verão, quando manifestam seu potencial máximo de crescimento, as gramineas tropicais são altamente preferidas às leguminosas (STOBBS, 1975).

Com efeito, STOBBS (19́77), utilizando vacas Jersey fistuladas no esōfago, em pastagens de Setaria/Siratro submetidas a pastejo contínuo de novilhos Hereford, a taxas de 1,11 e 2,96 cab/ha, encontrou que a leguminosa foi selecionada no outono, apresentando maior proporção na dieta que na pastagem. 0 inverso foi observado nas demais épocas do ano, com exceção da primavera, nos pastos pesadamente pastejados (2,96 cab/ha), em que houve uma baixa disponibifidade de forragem verde (424 kg de MS/ha) e de Siratro ( $8 \mathrm{~kg}$ de $M S / h a)$, cuja participação na dieta foi semelhante à da pastagem. Admite esse autor, que sob condições de pastejo moderado, o Siratro é menos palatável na primavera e verão, o que permite o seu crescimento vigoro so e como no outono torna-se altamente palatável, com teores relativamente altos de proteina e digestibilidade, possibilita a manutenção do crescimento dos animais no inverno seco. Em condições de curral, foi en- 
contrado que tanto o Siratro colhido no verão e outono foram menos, preferidos pelos animais, quando oferecidos juntamente com o capim Pangola coIhido no outono; e que o Siratro de outono foi mais palatável que o de ve rão (STOBBS, 1977).

KALIL (1977), referindo-se a experimento realizado por PEDREIRA et alii (1961), recomenda pastejo rotativo para pastagens de certas gramíneas e Soja perene (Glycine wightij), uma vez que o animal dā preferēncia à gramīnea, transformando a ārea, se o pastejo for contínuo, em pastos de Soja perene apenas.

Segundo ROBERTS (1979), a carga animal è o fator mais importante para a estabilidade e produtividade a longo prazo de uma pasta gem de graminea/leguminosa tropicais. Para esse autor o superpastejo leva a um declínio na proporção de leguminosa na pastagem e a isto se seguirā uma aguda queda na produção animal.

0 animal em pastejo tem a oportunidade de selecionar aquela planta, e parte dela, que The $\bar{e}$ mais aceitāvel. A extensão em que um componente de uma comunidade de plantas é ingerido (aceitabilidade), reflete as respostas sensōrias aos estímulos produzidos pelas característi cas quīmicas e físicas, favoráveis ou desfavorāveis, da planta, no momento em que o animal a encontra; entretanto, essa aceitabilidade pode ser modificada pela experiéncia desse animal (ARNOLD, 1970).

Trēs mecanismos são considerados para explicar o comporta mento fāgico de animais: a) eufagia, seleção de uma dieta direcionada para uma nutrição ōtima; b) edifagia, seleção do alimento pelo gos to agradá vel, e c) eufagia específica, seleção no sentido de um nutriente especí fico. (ARNOLD, 1970). 0 mesmo autor relata haver maiores evidericias de que a eufagia é secundāria à edifagia, como mecanismo motivador do pastejo se letivo, e de não ocorrer eufagia especîfica em ruminantes. Relata, ainda, que quando hā abundāncia de forragem, o animal pode expressar livremente suas preferéncias; entretanto, quando o suprimento de forragem decresce, ele é forçado a ingerir material menos aceitável, sob pena de passar fome.

Os resultados encontrados por CHACON e STOBBS (1976) estão 
em acordo com essas assertivas e enfatizam a importāncia do componente fo liar para o animal em pastejo. A baixa pressões de pastejo, os animais puderam pastejar seletivamente as partes folhosas mais nutritivas da pastaçem; entretanto, com a sua progressiva defoliação, houve uma redução na oportunidade de selecionarem, sendo então forçados a consumirem dietas progressivamente pobres em folhas e com crescentes conteūdos de colmos e, por fim, de material senescente. Esses mesmos A.A. relatam, ainda, que, em um dos seus experimentos, o material morto compreendeu uma pequena proporção (8\%) da dieta de vacas em pastejo no outono, enquanto na primavera a proporção desse material foi negligível.

Da mesma forma, LOURENÇO et alii (1979a e 1979b), em estudo de dieta de bovinos fistulados no esōfago, em pastagens de Brachiaria. decumbens, Stapf, encontraram que, com o aumento da taxa de lotação, a percentagem de folhas verdes decresceu na dieta, enquanto a participação de folhas secas, caules verdes e caules secos aumentou. Constataram, tambēm, uma maior presença de material seco no periodo "seco" (não chuvoso). As percentagens de caules verdes e material seco (folhas secas e caules secos) na dieta foram inferiores às da pastagem, em todas as lotações. Inversamente, as percentagens de folhas verdes, foram superiores na dieta em relação ao pasto.

A completa liberdade de escolha é raramente possível, particularmente sob condições de pastejo onde a estrutura da pastagem pode restringir o acesso a alguns dos componentes, e onde as proporções dos di ferentes componentes começa a mudar tão logo o pastejo é imposto(HODGSON, 1979). Para esse autor a seleção da dieta pelo animal em pastejo é a remo ção de alguns componentes da pastagem - plantas ou partes de plantas - ao invēs de outros. A "razão de seleção" é por ele definida como a proporção de um componente na dieta, dividida pela sua proporção na pastagem, descrevendo o grau de seleção exercido no sentido ou contra um determinado componente.

Por outro lado, a quantidade de forragem ofertada determina a capacidade de suporte de uma pastagem, e a qualidade dessa forragem condiciona o nível de produção por animal (MINSON et alii, 1976). Mensura ções da disponibilidade e composição botānica da matéria seca produzida possibilitando estimativas de crescimento, utilização, deteriorização ou 
persistência dessa pastagem - combinada com medições da composição quîmica e digestibilidade da forragem ofertada, tem sido utilizadas, adequadamente na interpretação da influēncia dos atributos da pastagem no desempenho ani mal e vice versa ('t MANNETJE, et alii, 1976).

No que se refere ao crescimento da pastagem, a utilização da energia solar - fator básico e limitante da produção vegetal - pode ser restringida por outros fatores climáticos como baixas temperaturas e deficiēncias hîdricas, a lém da carēncia de nutrientes (COOPER e TAITON, 1968).

PEDREIRA (1973a), em experimento realizado em Nova Odessa, Estado de São Paulo, por 5 anos consecutivos, visando avaliar o crescimento estacional de quatro gramineas forrageiras tropicais, entre as quais o cap̣im Colonião (Panicum maximum, Jaç), obteve, afora outros, os seguintes resultados: 1) as taxas minimas de crescimento de cultura foram estrei tamente relacionadas com as temperaturas minimas registradas, bem como as taxas minimas o foram em relação às temperaturas máximas; 2) para o colo nião, em particular, os meses associados com as menores taxas de crescimen to foram junho, julho e agosto, sendo que a menor taxa se deu em julho (2 kg de MS/ha/dia); 3) a taxa de crescimento diārio máximo do Colonião se deu em janeiro (64 kg de MS/ha/dia); 4) durante o perīodo de crescimento mais intenso, a curva desse crescimento foi bem similar à curva de pluviosidade.

Também em Nova Odessa, PEdREIRA (1973b) estudou o ... crèscimento estacional das leguminosas Siratro, Soja Perene e Stylosanthes guyanensis, tendo encontrado que a produtividade da Soja foi bastante concentrada no verão (meado de outubro a meado de abril). Na primavera hā um rāpido incremento na cuürva de Grescimento dessa leguminosa até um pico de aproximadamente $45 \mathrm{~kg}$ de $\mathrm{MS} / \mathrm{ha} / \mathrm{dia}$, no fim dessa mesma estação. De meado de dezembro a meado de janeiro a Soja Perene baixa seu ritmo para $35 \mathrm{~kg}$ de MS/ha/dia, mantendo essa velocidade até o fim de março quando então cai ra pidamente, atingindo seu ponto de menor produtividade em junho-julho.

Vários métodos tém sìdo utilizados na estimativa da composição botānica da dieta selecionada por ruminantes, em pastagens. 
Em anos recentes, o exame microscōpico de fragmentos de plantas, obtidos do trato digestivo e fezes do animal, tém sido crescente mente usados para avaliar a composição florística dos componentes ingeridos de diferentes vegetações (TOTHILL, 1978), e a necessidade de obtenção de amostras do material ingerido tem levado ao uso de animais com fístula de esōfago e de rúmem (THEURER, 1970; citado por MINSON et alii, 1976).

Fístulas de rúmem são, em geral, mais fáceis de estabele cer e manter, porēm os procedimentos de amostragem são mais complexos, pela necessidade de esvaziamento do rúmem antes de cada período de pastejo, o que pode afetar adversamente o comportamento do animal (MINSON et alii, 1976). Além disso, a retirada da forragem consumida e reposição do conteūdo ruminal, outras operações envolvidas nessa técnica, consomem maior tempo que em amostragens com fístulas esofägicas, sem considerar., ainda, que a evacuação do rúmem não é adequada para repetidas amostragens, em condições de campo (VAN DYNE e TORELL, 1964).

FREE et alii (1971), em estudo comparativo dos métodos de "contagem de bocadas" ("bite count") e exame microscōpico de amostras obtidas de fístula de esōfago, não encontraram diferenças significativas na estimativa da composição botānica de dieta de novilhos, em pastagens nativas. As vantagens atribuidas pelos A.A. ao método "contagem de bocadas" referem-se ao menor requerimento de tempo para treinamento dos obser vadores e por dispensar o uso de animais fistulados no esōfago. Todavia é questionável a factibilidade desse mētodo em pastagens constituidas de gramīneas cespitosas entremeadas com leguminosas grimpantes, em que se ve rifica a ingestão simultānea dos dois componentes e em variadas proporções.

Baixas correlações foram encontradas entre as composições botānicas das dietas de novilhos, determinadas atravēs de exame microhistolögico do material fecal e amostras coletadas de animais fistulados no esōfago, tendo em vista a digestão diferenciada das vārias espécies presentes na dieta (VAVRA et alii, 1978). Entretanto, uma classificação por valor de importāncia, revelou que amostragens da fístula e de fezes foram similares, quando as espécies, individualmente, foram classificadas da mais comum à menos comum na dieta. Concluiram ainda, aqueles A.A., que 
a anālise fecal pode ser usada quando o grau de exatidão desejado é menor e onde não se dispõe de animais dōceis e manejāveis. SLATER e JONES (1971) recomendam cuidado no uso de exame microscópico de fezes para esti mativa da composição botānica de dietas, onde as leguminosas formam a base de pastagens mistas melhoradas, em virtude da destruịção da epiderme dessas espécies, durante a passagem pelo trato digestivo do animal.

$$
\text { Recentemente, um método foi proposto por JONES et alii }
$$

(1979), para estimativa da proporção de plantas $C_{3}$ e $C_{4}$ na dieta de ani mais, a partir da relação de isōtopos naturais ${ }^{12} \mathrm{C}$ e ${ }^{13} \mathrm{C}$ nas fezes. Esse método é particularmente sugerido para pastagens cultivadas tropicais de gramīnea/leguminosa, não fazendo, porēm, discriminação no caso de vārias espécies dentro dessas familias. Embora a percentagem da leguminosa possa ser predita com desvio padrão de $3 \%$, esse método tem seu emprego restrito pela lenta marcha das determinações e o alto custo do espectrōmetro de massa.

$\mathrm{Na}$ presente revisão foi constatada a existēncia de poucos trabalhos que tratem especificamente de pastejo seletivo em pastagens tro picais mistas, dentro do enfoque aqui pretendido. Em nossas condições inexistem trabalhos dessa natureza. 


\section{1. - Periodo e Area Experimental}

Os resultados desse estudo foram obtidos a partir de amostragens realizadas em 26-30/janeiro, 01-05/março, 05-09/abri1, 10-14/ maio, 06-10/agosto, 24-28/setembro e 12-16/novembro, em ensaio de pastejo conduzido no periodo janeiro-novembro/1979, em pastagem tropical mista. Esta pastagem era constituida de capim Colonião (Panicum maximum, Jacq) e Soja Perene (Glycine wightii, Wild), invadida por grama Batatais (Paspalum notatum, Flugge), com ocorréncia de outras gramīneas (predominantemen te Brachiaria mutica (Forsk) Stapf), tendo sido estabelecida há cerca de 7 anos numa área de 2,93 ha, pertencente ao Departamento de Zootecnia da ESALQ, no Estado de São Paulo, com coordenadas de $22042^{\prime} \mathrm{S}, 47038^{\prime} \mathrm{W}$ e alti tude de $500 \mathrm{~m}$.

Essa pastagem, anteriormente ao período experimental, era submetida a pastejo intermitente, de moderada intensidade, tendo sofrido uma queima acidental em 21.10.78, que a atingiu severamente em sua quase totalidade. Em princípio de janeiro e fim de março de 1979, respectivamen te, foram constatados dois ataques de lagartas na Soja perene, com danos substanciais para sua àrea foliar, notadamente no segundo ataque.

\subsection{1. - C1ima}

o clima da região caracteriza-se, segundo classificação de 
Koeppen, como sub-tropical com inverno seco (Cwa) e, de acordo com a clas sificação de Thornthwaite, como do tipo úmido com pequena deficiēncia de āgua, megatérmico, com pequena oscilação térmica no ano $\left(C_{2} r A^{\prime} a^{\prime}\right)$ (VILLA NOVA, 1980).

As normais climáticas registradas nos perĩodos $1917 / 1970$, pelo Departamento de Física e Meteorologia da ESALQ, constam na Tabela 1. Na Tabela 2 estão os dados meteorológicos ocorridos no ano experimental.

Tabela 1 - Normais climáticas da Região (1917/1970).

\begin{tabular}{lccc}
\hline \multicolumn{1}{c}{ Meses } & Temp. (ọ $)$ & $\begin{array}{c}\text { Umidade } \\
\text { Relativa(\%) }\end{array}$ & Precipitação (mm) \\
\hline Janeiro & 23,6 & 75 & 223 \\
Fevereiro & 23,5 & 76 & 189 \\
Março & 23,1 & 75 & 132 \\
Abri1 & 21,7 & 71 & 61 \\
Maio & 18,4 & 72 & 47 \\
Junho & 17,0 & 72 & 41 \\
Julho & 16,7 & 67 & 24 \\
Agosto & 18,5 & 60 & 29 \\
Setembro & 20,4 & 60 & 60 \\
Outubro & 21,5 & 57 & 104 \\
Novembro & 22,5 & 67 & 121 \\
Dezembro & 23,2 & 71 & 206 \\
\hline
\end{tabular}


Tabela 2 - Dados meteorológicos ocorridos no ano experimental (1979).

\begin{tabular}{lccc}
\hline \multicolumn{1}{c}{ Meses } & Temp. (ỌC) & $\begin{array}{c}\text { Umidade } \\
\text { Relativa(\%) }\end{array}$ & $\begin{array}{c}\text { Precipitação } \\
(\mathrm{mm})\end{array}$ \\
\hline Janeiro & 22,2 & 74,7 & 122,4 \\
Fevereiro & 23,7 & 77,3 & 114,4 \\
Março & 22,3 & 75,7 & 84,7 \\
Abri1 & 20,0 & 75,7 & 63,9 \\
Maio & 18,5 & 80,7 & 96,9 \\
Junho & 16,4 & 73,2 & 00,0 \\
Julho & 16,0 & 71,3 & 28,0 \\
Agosto & 19,7 & 70,4 & 81,4 \\
Setembro & 19,7 & 75,9 & 98,6 \\
Outubro & 23,4 & 75,0 & 101,4 \\
Novembro & 22,6 & 73,0 & 102,8 \\
Dezembro & 24,5 & 80,6 & 105,7 \\
& & & \\
\hline
\end{tabular}

Nos dias 37 de maio e 10 de junho do ano experimental veri ficou-se a ocorréncia de fortes geadas, que afetaram severamente a pastagem objeto de estudo e de forma diferenciada os seus componentes botāni cos. Em 36 de julho do mesmo ano, repetiu-se o fenōmeno, desta vez com me nor intensidade, sem afetar significativamente a forragem disponível.

\subsection{2. - Topografia e Solo}

A topografia é suave-ondulada, com declividade não exceden do a $5 \%$. Uma pequena depressão atravessa transversalmente a ārea experimental (Fig. 1) a qual fica sujeita a encharcamento por curtos períodos que seguem a fortes chuvas.

O solo, segundo DEMATTE (1980), foi identificado como sendo uma mistura de terra roxa estruturada (tropudalf), com molissol. Sua anālise quỉmica, revelou os seguintes valores, contidos na Tabela 3. 
Tabela 3 - Análise quîmica do solo fornecida pelo Deptọ de Solos da ESALQ

\begin{tabular}{|c|c|c|c|c|c|c|}
\hline & Carbono & Teor & trocāvel & em milieq & lentes & \\
\hline $\mathrm{pH}$ & $\begin{array}{c}\text { Organico } \\
(\%)\end{array}$ & $\mathrm{PO}_{4}^{---}$ & $k^{+}$ & $\mathrm{Ca}^{++}$ & $\mathrm{Mg}^{++}$ & $\mathrm{Al}^{+++}$ \\
\hline 5,9 & 1,44 & 0,03 & 0,71 & 8,24 & 2,08 & 0,08 \\
\hline
\end{tabular}

(a) T.F.S.A. = Terra fina seca ao ar (partículas menores que 2 mm).

Em 18 de janeiro/79 foi feita uma aplicação manual, em co bertura, de $80 \mathrm{~kg}$ de $\mathrm{P}_{2} \mathrm{O}_{5}$, na forma de superfosfato simples, e de $50 \mathrm{~kg}$ de $\mathrm{K}_{2} \mathrm{O}$, na forma de cloreto de potássio.

\subsection{3. - Manejo da Pastagem}

Na fase pré-experimental, durante o período de crescimento rápido que seguiu ao inīcio da estação chuvosa, foi introduzido um grupo de animais (12 cabeças), para conter o crescimento acelerado do pasto, particularmente do capim Colonião, e estabelecer uma estrutura desejāvel da vegetação. Após esse rebaixamento inicial da pastagem, foi mantida, a partir de 07.17.78, uma carga animal idēntica à que seria então adotada na fase experimental.

0 piquete foi submetido a pastejo contínuo durante toda a duração do ensaio. A previsão inicial era manter uma carga animal fixa de 2,3 cabeças/ha (I novilhos/2,93 ha). Entretanto, com a ocorréncia de geadas, já mencionadas, que reduziram drasticamente a forragem ofertada (cer ca de $40 \%$ ), fez-se necessária uma redução dessa lotação, procurando-se sua proporcionalidade com a redução de forragem estimada. Assim, em 02. 06.79, foram retirados da ārea experimental 3 animais, sendo que dois des tes eram reservas e o terceiro efetivo. Este ūitimo foi reintroduzido no pasto durante as $5^{\underline{a}}$ e $6^{a}$ amostragens, no perīodo em que foi mantida uma carga de 4 cabeças no piquete. A partir do final da $6^{2}$ amostragem foi res tabelecida a carga animal inicial de 2,3 cabeças/ha, com o inīcio de novă estação de crescimento. 


\section{2. - Animais Experimentais}

Foram utilizados 7 novilhos de sobre-ano, 5/8 europeu (raças leiteiras) $\times 3 / 8$ zebu, com $214 \pm 10 \mathrm{~kg}$ de peso vivo, ao início do experimento, e $343^{ \pm}-12 \mathrm{~kg}$, ao final do mesmo, cinco deles trabalhados como amostradores e os demais foram mantidos como reserva e para fins de carga animal.

Esses animais foram fistulados no esōfago, segundo a tēcni ca descrita por BISHOP e FROSETH (1970), em novembro e dezembro de 1978. Antes e após a cirurgia foi-lhes proporcionado um manejo contīnuo, de modo a acostumá-los ao contato cotidiano com os experimentadores e à manipu lação das fístulas. Na fase pós-operatōria foram dispensados cuidados terapéuticos prescritos pelo médico-veterinārio executor da cirurgia, atē o satisfatōrio estabelecimento das fístulas.

Em função das diferentes datas de operação dos animais, os periodos de adaptação dos mesmos ao manejo e à pastagem experimentais foi variāvel. Entretanto, observou-se um período mīnimo de 15 dias da entrada dos ūltimos novilhos fistulados na ārea experimental, antes de serem iniciadas as amostragens. Neste espaço de tempo foi treinada toda a metodolo gia de campo e selecionados os cinco animais com os quais seriam feitas as mensurações e inferēncias.

As cānulas utilizadas foram basicamente do tipo ilustrado na Figura 3 C por VAN DYNE e TORELL (1964), com dimensões adaptadas para bovinos e com a adição de um disco externo de acrîlico transparente (vide Fig. 2), destinado a evitar a entrada da cānula no esōfago e proteger os bordos das fístulas de eventuais mî̃ases. Inicialmente usou-se cānulas em que a parte A (espátula) (Fig. 2), que permanece no interior do esōfago, era confeccionada de material plāstico flexīvel, guarnecida, na parte cōn cava, por uma lāmina de aço inoxidāvel. Por sofrerem deformações provocadas pelo fluxo de material ingerido e regurgitado pelo animal, tais peças ocasionavam obstruções parciais da luz do esófago, interferindo no compor tamento de pastejo e tornando necessārias a remoção e lavagem diārias das cānulas. No período de 14 a 27 de abril ocorreram perdas sucessivas de cá nulas, por efeito de quebra das mesmas em quatro dos animais experimen- 
tais, com consequentes efeitos estressantes, provocados por perdas excessivas de saliva, extravasamento de material do rūmem e fechamento das fís tulas. Em substituição foram usadas novas cānulas, em que as espātulas eram feitas de PVC rígido, as quais propiciaram uma diminuição significati va do desconforto experimentado pelos animais, minimizando eventuais alte rações do comportamento ao pastarem. Devido a esse melhor ajuste fístula/ cānula, as lavagens e remoções das cānulas passaram a ser efetuadas uma vez por semana, embora as inspeções externas continuassem diārias.

As bolsas de coleta foram feitas de lona impermeāvel, providas de drenos para escoamento do excesso de saliva, as quais eram presas aos animais por quatro pares de correias, conforme ilustrado nas Figu ras 3 e 4 .

Durante todo o período experimental foi proporcionado consumo "ad libitum" de uma mistura mineral contendo sal comum, farinha de ossos e micronutrientes, tendo, os animais, livre acesso à àgua, fornecida em bebedouro.

Foram efetuadas as vacinações de praxe contra carbūnculo sintomātico e febre aftosa e, ainda, everminações periōdicas (a cada 3 me ses). Os ectoparasitos foram controlados sempre que atingiam níveis consi derados criticos no manejo normal dos animais do Departamento.

As pesagens foram feitas no 20 dia de cada período de amos tragem, sempre às 09:00-09:15, sem jejum prévio, tal como recomendado por 't MANNETJE, et alii (1976).

\section{3. - Amostragens}

\subsection{1. - Composição Botānica da Forragem Ingerida}

Durante 4 dias consecutivos de cada perīodo de amostragem, foram coletadas amostras da forragem ingerida pelos animais fistulados, em bora, em alguns casos, por ocorréncia de regurgitação e contaminação das amostras com material do rümem, fosse necessāria a repetição das coletas prejudicadas .

Em cada dia de amostragem os animais eram contidos por vol 


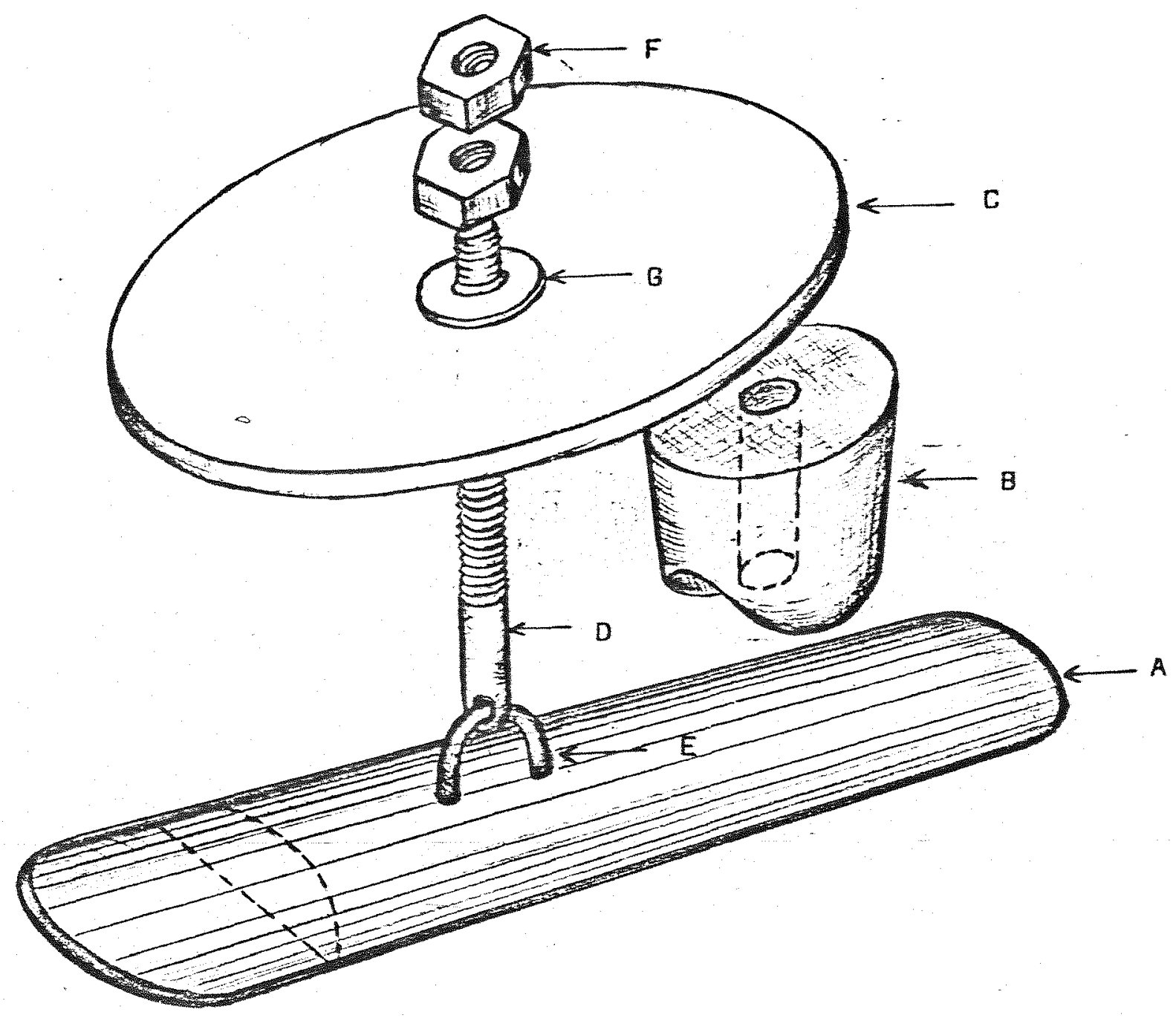

Fig. 2 - Ilustração do tipo de cānula utilizada no experimento.

A - Espátula de PVC rígido de $2 "(12 \times 3 \mathrm{~cm})$

B - Rolha de borracha (diāmetro $3 \mathrm{~cm}$, altura $3 \mathrm{~cm}$ )

C - Disco de acrîtico transparente (diāmetro $7 \mathrm{~cm}$, espessura $0,5 \mathrm{~cm}$ )

D - Parafuso de metal de 1/4"

$E$ - Arame de metal que une $A$ a $D$

F - Porcas de metal de 1/4"

G - Arruela de metal 


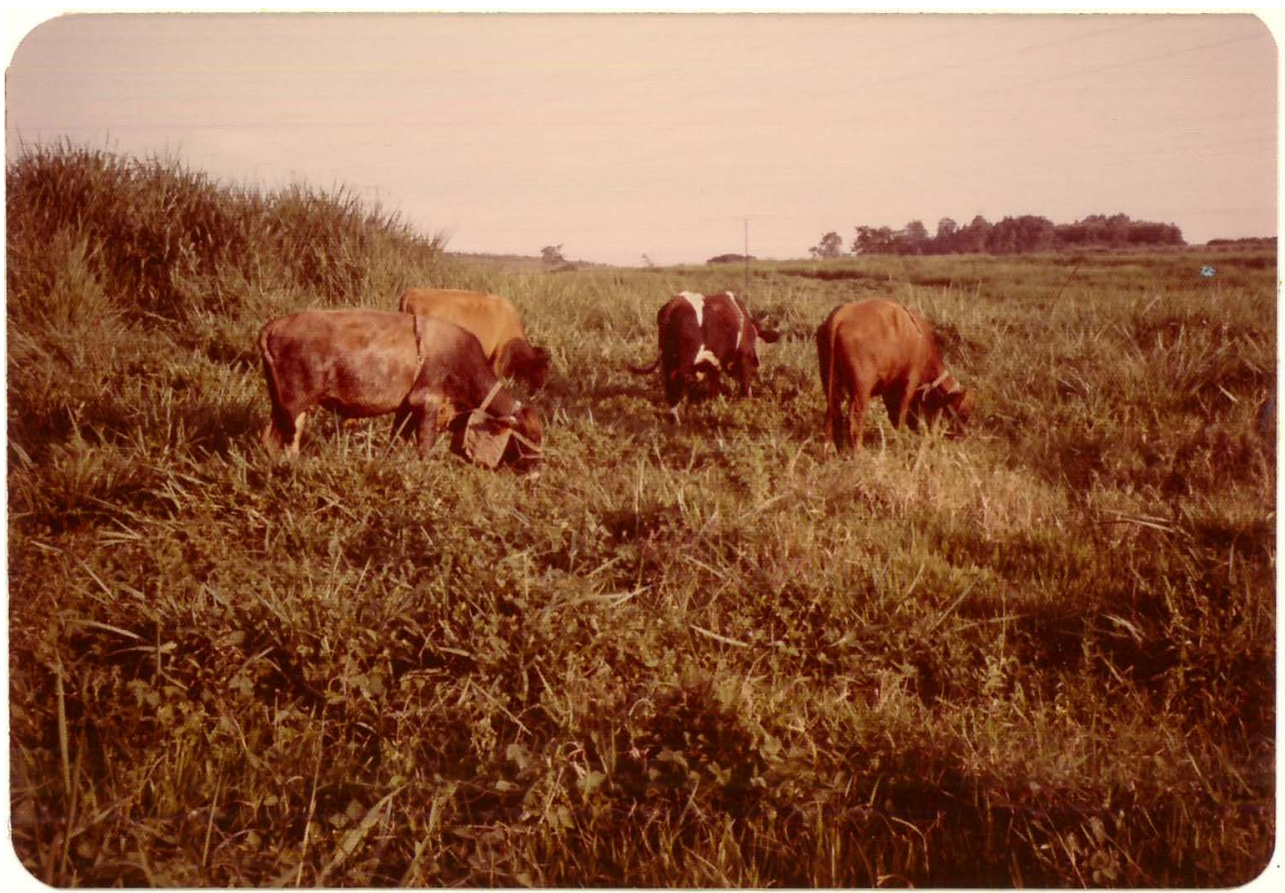

Fig. 3 - Animais equipados com sacolas, em coleta de amostras da dieta. 


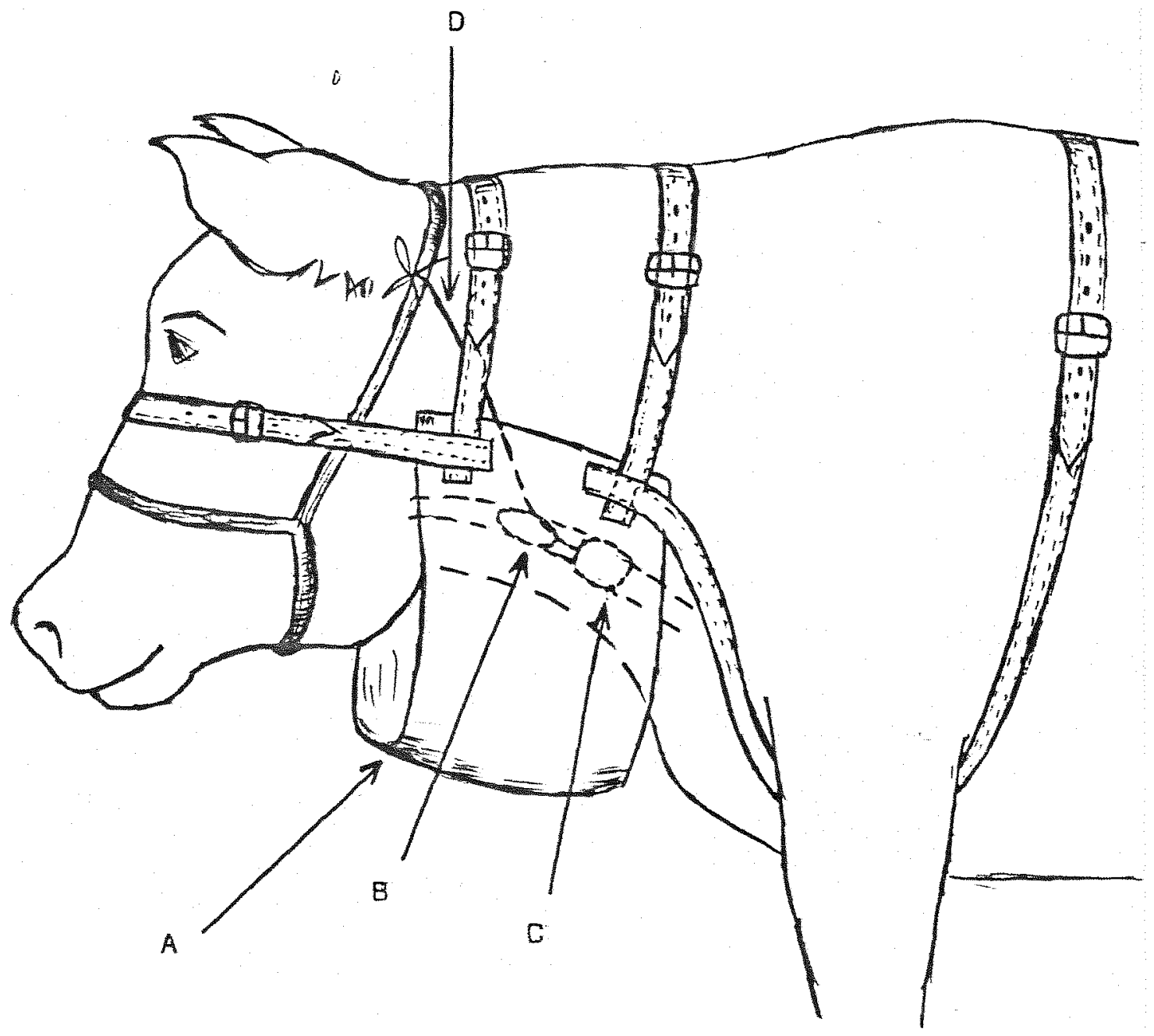

Fig. 4 - Ilustração esquemática dos acessórios usados na amos tragem da diet.a.

A - Sacola de lona com drenos

B - Fistula

C - Bucha de espuma de borracha

$D$ - Cordão de nylon que prende $C$ ao cabresto 
ta das 12:30 - 13:00. Ās 16:30, apōs remoção das cānulas e colocação das sacolas, eram liberados para 25-35 minutos de pastejo, com um minimo de perturbação no seu comportamento seletivo. Em seguida eram novamente contidos, para retirada das sacolas coletoras contendo material ingerido e recolocação das cānulas, sendo soltos ao pasto até nova coleta no dia seguinte. Em quatro animais amostradores fez-se uso de "buchas" de espuma" de borracha, que eram inseridas na parte baixa do esōfago, atravēs da fís tula, permanecendo atadas ao cabresto do animal. Conforme sugerido por MINSON et alii (1976), esta medida permitiu maior recuperação do material ingerido, conseguindo-se amostras de 800-1600 g, em média.

Das sacolas, as amostras correspondentes a cada animal eram transferidas para sacos plāsticos, devidamente identificados, e levadas para o laboratōrio onde, apōs homogeinização, eram retiradas $300-400$ g para anāilises quỉmicas e outras determinações objeto de outra tese. 0 restante era então colocado em um recipiente suficientemente amplo, ao qual era adicionado āgua em quantidade capaz de promover uma boa uniformi zação do material, para posterior retirada de 100 g: destinadas à separação botānica. Essas sub-amostras eram guardadas em congelador, atē a sepa ração botānica.

\subsubsection{1. - Separação Botānica das Amostras}

A composição botānica das amostras obtidas pelos animais fistulados foi determinada por separação manual, conforme técnica descrita por MINSON et alii (1976), com o auxilio de uma lupa binocular. Por ser esse método muito trabalhoso, as amostras coletadas por cada animal, nos quatro dias, foram agrupadas em sub-amostras compostas dos 10 e 20 dias e 30 e 40 dias, respectivamente. Das sub-amostras estoca das (100 g), retirava-se $10 \mathrm{~g}$ desse material, que eram então colocadas em placas de Petri contendo ägua e levadas ä lupa para separação manual, com ajuda de uma pinça.

Durante a separação, o material era distribuido em vidros de relōgio, nos seguintes componentes: Colonião, Soja Perene, Grama Batatais, Outras Gramīneas, Outras Leguminosas, Ervas e Arbus tos e Material Morto, sendo que es te ültimo componente não era discrimina 
do botanicamente. Ao fim de cada separação, os componentes foram coloca dos ém estufa a 1059C, por 4 horas, para determinação do peso seco. A participação percentual de cada componente foi calculada em relação ao so matōrio dos pesos secos dos mesmos, exceto o material morto, cuja partici pação foi tomada em relação ao total de matēria seca separada.

Dentro de cada componente botānico, para determinação do peso seco, foram computadas todas as partes das plantas que foram identificadas, porēm sem discriminação. As partes predominantes foram folhas e hastes, em gramineas, e folhas e estolões, em leguminosas.

Cada separação teve uma duração média de cerca de 2-4 horas, em decorrēncia de diferentes graus de mastigação da forragem pelos animais, os quais determinaram grande variação no tamanho das particulas e, consequentemente, na identificação destas. 0 percentual de material se. parado variou de $50-70 \%$ das $10 \mathrm{~g}$ examinadas.

Para verificação do grau de exatidão das separações, pelos estimadores, foi feita, paralelamente, uma calibração das estimativas.Com base nas composições estimadas, preparou-se amostras contendo os principais componentes da dieta, que foram em seguida separados e correlaciona dos com os valores conhecidos. O material para preparação destas amostras foi obtido dos componentes referidos, oferecidos individualmente, em cocho, a dois dos animais e em seguida coletados pelas fístulas. Esses componentes foram colhidos do pasto a mão, à semelhança do pastejo efetuado pelos animais (hand plucking), durante as quatro primeiras amostragens.

\subsection{2. - Composição Botānica da Forragem Disponĩvel}

Nos mesmos dias de coleta do material ingerido pelos animais fistulados, foram feitas as amostragens para determinação da composi ção botānica da forragem disponīvel na pastagem.

Inicialmente dividiu-se a ārea em diversos estratos

(ver Fig. 1) em função da variabilidade da vegetação, localizando-se em cada estrato um nọ de parcelas proporcional à participação percentual aproximada da ārea de cada estrato em relação à ārea de pastagem em estudo. Ao todo foram fixadas 20 parcelas de $12 \mathrm{~m}^{2}$, procurando-se a maior unifor- 
midade possível dentro de cada parcela, quanto à vegetação nela contida.

0 método utilizado para estimativa da forragem disponível e sua composição botánica, foi o de dupla amostrag̣em, por estimativa de peso verde calibrado (TADःOR et alii, 1975). Em cada parcela era colocado um quadrado de $7 m \times 1 \mathrm{~m}$, fazendo primeiro uma estimativa visual do peso fresco de cada componente considerado, apōs o que era cortada toda a biomassa a cerca de $5 \mathrm{~cm}$ do solo, que era então separada manualmente, no 10cal, em: Colonião, Soja Perene, Batatais, Outras Gramineas, Outras Legumi nosas, Ervas e Arbustos e Material Morto (partes senescidas das plantas, acima de $5 \mathrm{~cm}$ do solo, sem discriminação botānica). Eram, em sequida, registrados os pesos de cada componente, individualmente, e feitas estimatj vas visuais desses mesmos componentes em mais quatro quadrados colocados na mesma parcela. Esse procedimento foi repetido para todas as parcelas, durante os 4-5 dias de amostrạem, em toda a duracão do ensaic. Entretanto, ao final do estudo, constatou-se que, a partir da amostragem de agosto, as correlaçōes entre os valores correspondentes às estimativas visuais e os valores observados (cortes) foram bastante baixas, sem significa ção estatística, o que levou a considerar-se apenas os cortes, para estimativa da composição botānica da forragem disponīvel.

\subsection{3. - Seletividade de Pastejo}

Para avaliação do grau de seletividade de pastej•, no sentido ou contra um determinado componente, foi usada a expressão proposta por HODGSON (1979): razão de seleção = proporção de um componente na dieta, dividida pela proporção do mesmo na pastagem:

$$
\cdots\left(R S=\frac{\% \text { Dieta }}{\% \text { Pasto }}\right)
$$

\section{4. - Anāitises Estatísticas}

Anāitises de variāncia foram usadas para estudo da variação das percentagens de cada componente botānico na dieta dos animais, ao ion go das épocas estudadas, e das razões de seleçäo desses componentes, conforme esquema a seguir: 
Componentes da dieta ( $\%$ de Colonião, \% de Soja Perene, \% de Batatais, etc.).

\begin{tabular}{lr} 
CV & $\mathrm{GL}$ \\
\hline Epocas & 5 \\
Animais & 4 \\
Epocas X Animais & 20 \\
Dias & 1 \\
Erro & 29 \\
& \\
\hline Total & 59
\end{tabular}

Razões de Seleção (RS do Colonião, RS da Soja Perene, RS de Batatais,..... etc.).

\begin{tabular}{lc} 
CV & $\mathrm{GL}$ \\
\hline Epocas & 5 \\
Animais & 4 \\
Erro & 20 \\
& \\
\hline Total & 29
\end{tabular}

Todos os dados obtidos em \% foram transformados a àngulo do arco seno da $\sqrt{x \%}$, para atender às exigências das ANAVAS (SNEDECOR e COCHRAM, 1967). Com o mesmo fim, foram feitos os testes de normalidade dos dados (Teste $!$ ) (ANDERSON e MACLEAN, 1974) e homogeneidade de variāncia (SNEDECOR e COCHRAM, 1967).

0 teste de Duncan foi usado para comparação das médias. 
24.

5. RESULTADOS E DISCUSSÃO

\section{1. - Forragem Disponível.}

A forragem disponīvel na pastagem, em termos de matēria seca a 1009C, e sua composição botānica, nas épocas estudadas, estão contidas na Tabela 4. A Figura 5 ilustra a tendéncia desses dados ao longo do tempo, a par dos valores correspondentes aos pesos vivos dos animais, além dos relativos às temperaturas mensais médias e pluviosidade registrados no perīodo experimental. A Tabela 5 contēm as quantidades de forragem disponī vel por unidade animal (U.A.).

Os resultados obtidos revelaram que o total de matéria seca (MS) disponível aparentemente sofreu variações estacionais nas ēpocas amos tradas. Nas amostragens efetuadas em agosto e setembro, verificou-se uma redução acentuada nos componentes da forragem verde (material vegetativo), em decorréncia, inicialmente, da geada ocorrida em maio, agravada em segui da pela baixa pluviosidade e queda de temperatura, registradas em junho-ju 1ho, fatores limitantes da rebrota das pastagens nesta época do ano, tal como mencionado por COOPER e TAITON (1968) e PEDREIRA (1973a e 1973b). In versamente, como consequéncia desses fatores e do pastejo, a quantidade de material morto elevou-se a partir da ocorréncia da geada, até atingir 53\% 
do total de MS disponível na pastagem durante a amostragem de setembro, declinando em seguida, por efeito de sua fragmentação, lixiviação e mineralização, em resposta aos aumentos de pluviosidade e temperatura que se seguiram.

0 capim Colonião que respondeu por $54,5-80,6 \%$ da forragem verde disp̣onível durante o período do ensaio, sofreu em agosto e setembro $\underline{u}$ ma redução de 40\% em relação à disp̣onibilidade média de janeiro até maio, voltando a apresentar, em novembro, nivel semelhante ao inicial. No experimento realizado por PEDREIRA (1973a), em condições semelhantes de clima, as menores taxas de crescimento do Colonião ocorreram em junho, julho e agosto que se relacionaram com temperatura e pluviosidade baixas.

A Soja Perene teve sua disponibilidade decrescente a partir de abril, com reduções mais severas que o Colonião, tambēm cons.tatadas nas épocas de agosto e setembro: cerca de $76 \%$ em relação às énocas precedentes. E bem provável que a redução da ārea foliar, resultante do ataque de lagartas ao fim de março, tenha limitado a quantidade disponível nas épocas posteriores, já que o crescimento da Soja apōs essa época diminui rapidamente (PEDREIRA, 1973b). Em novembro não ocorreu o restabelecimento de um nível prōximo daquele inicial, provavelmente por efeito dos fatores atipicos mencionados e da pressão de pastejo mais elevada ao final do ensaiolapōs a amostragem de setembro), quando se retórnou à carga animal empregada no inīcio do experimento (Ver Tabela 6). Este acentuado aumento da pressão de pas tejo possivelmente restringiu a seletividade dos animais, forçando-os a ingerirem os componentes de suas dietas em proporções similares às encontradas na pastagem. Por terem as leguminosas tropicais taxas de crescimento po tencial inferiores às de gramīneas tropicais (LUDLOW e WILSON, 1970), é com preensivel que sua pẳ̇ticipação na forragem disnonivel tenha-se reduzido. De fato, PEDREIRA (1973a e 1973b) encontrou vaiores de $45 \mathrm{~kg}$ de MS/ha/dia e $62,5 \mathrm{~kg}$ de $M S / \mathrm{ha} / \mathrm{dia}$ nas taxas de crescimento de cultura para a Soja Perene e Colonião, respectivamente, no final da primavera. ROBERTS (1979), tambēm menciona que o superpastejo leva a um declinio na proporção de leguminosa na pastagem.

A grama Batatais foi um dos componentes mais drasticamente a fetados pelas geadas. Este fato e a tendéncia crescente de sua aceitabilida de pelos animais nas trés ūltimas épocas, podem exp̣licar sua baixa disponibilidade e participação na pastagem ao final do ensaio. 
Reduções acentuadas tambēm foram observadas na quantidade de Outras Gramineas disponivel nas épocas de agosto e setembro, conquanto percentualmente não se tenha notado igual intensidade. Em novembro, a ofer ta desse componente atingiu valores mais elevados, tanto em termos absolutos quanto relativos, o que pode ser explicado pela baixa aceitabilidade desse material pelos animais nessa época, como se verä adiante.

Os demais componentes (Outras Leguminosas, Ervas e Arbustos), presentes na pastagem em quantidades negligîiveis, sofreram tambēm efeitos do clima semelhantes à tendéncia geral da forragem disponīvel, com reduções das quantidades de MS nas épocas de agosto e setembro. Em termos relativos não se notou variações consistentes, possivelmente pela pouca in terferéncia do animal.

Os teores de matéria seca dos componentes botānicos da pastagem, nas diversas amostragens, são apresentados na Tabela 7.

\section{2. - Composição Botānica da Dieta e Seletividade}

Os componentes botānicos da dieta estimada dos animais, nas diversas épocas do ensaio, estão apresentados quantitativamente na Tabela 8 e ilustrados na figura 6. As razões de seleção (RS) dos principais compo nentes estão contidas na Tabela 9, com suas tendéncias ilustradas na Figura 6, a qual apresenta tambēm as pressões de pastejo imprimidas durante 0 experimento. 0 apēndice $A$ contēm as anālises de variancia desses resultados.

A participação do capim Colonião na forragem ingerida foi da ordem de 68,7-83,4\% durante as épocas amostradas, com variações ao 1ongo do tempio. Em maio observou-se uma elevação significativa na sua proporção em relação às épocas anteriores, mantendo-se nesse nivel até setembro e retornando à proporç̧ăo similiar à inicial, em novembro. Esse incremento parece ter sido associado ao baixo consumo relativo da grama Eatatais ob servado na amostragem de maio, que se estendeu até setembro, voltando a ter, em novembro, uma particinação não diferente estatisticamente $\quad(P<$ $0,05)$ da inicial.

Os valores de RS, encontrados para o Cclonião, diferiram ( $P$ $<0,05)$ do valor de referéncia (RS $=1,0)$, apenas no mes de março, cuja RS diferiu significativamente das demais Ënocas, com exceção de maio, indican do que houve seletividade de pastejo corsistente, no sentido dessa grami 


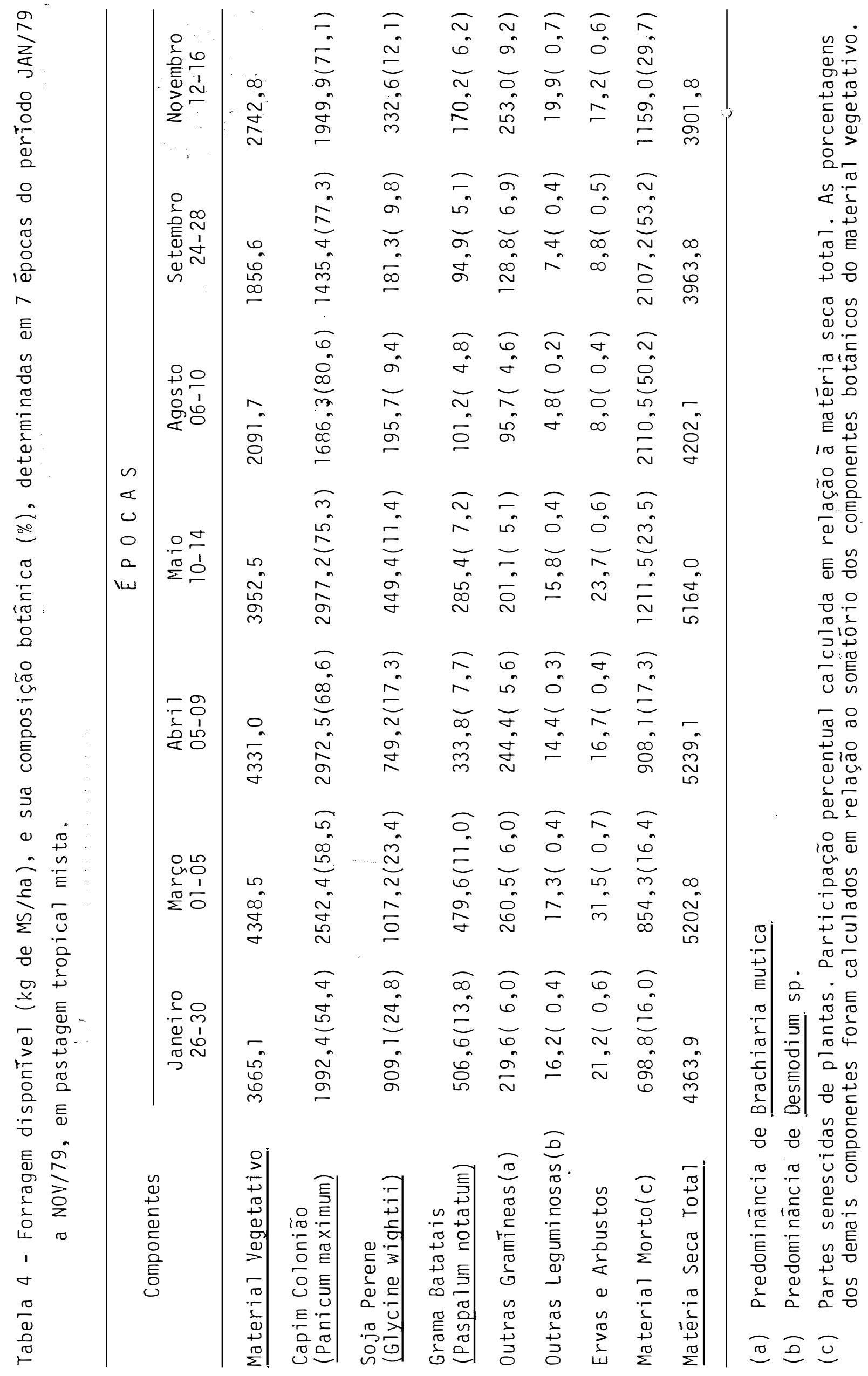



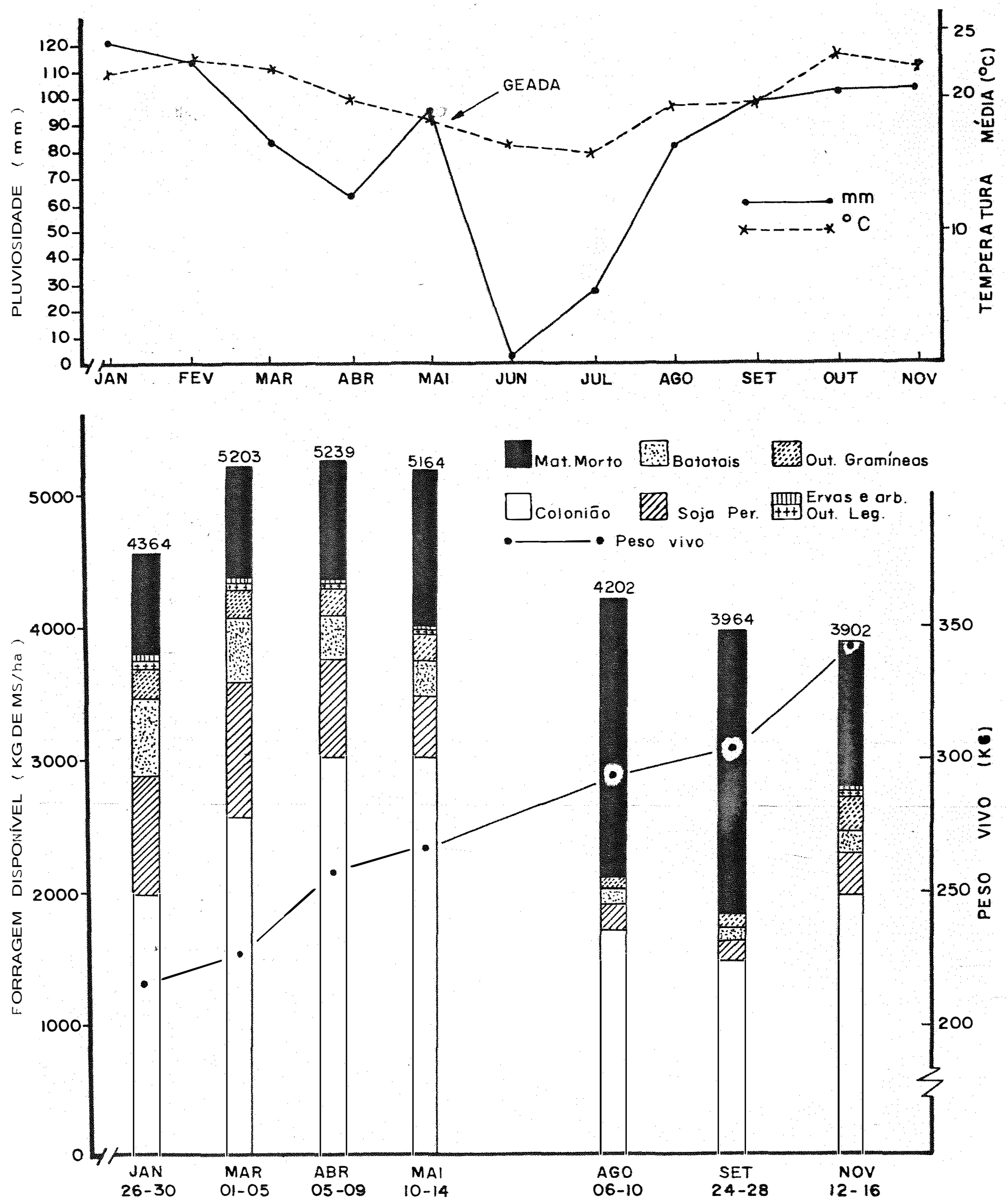

Fiọ. 5 - Forraģem disnonível ( $\mathrm{kg}$ de MS/ha) e sua composição botánica, determinadas em 7 épocas do perīodo JAN/79 a NOV/79, en pastag̣em tropical mista; peso vivo de novithos com: fistulas esofáģicas $(k g ̧)$ e parámetros climáticos de 1979. 


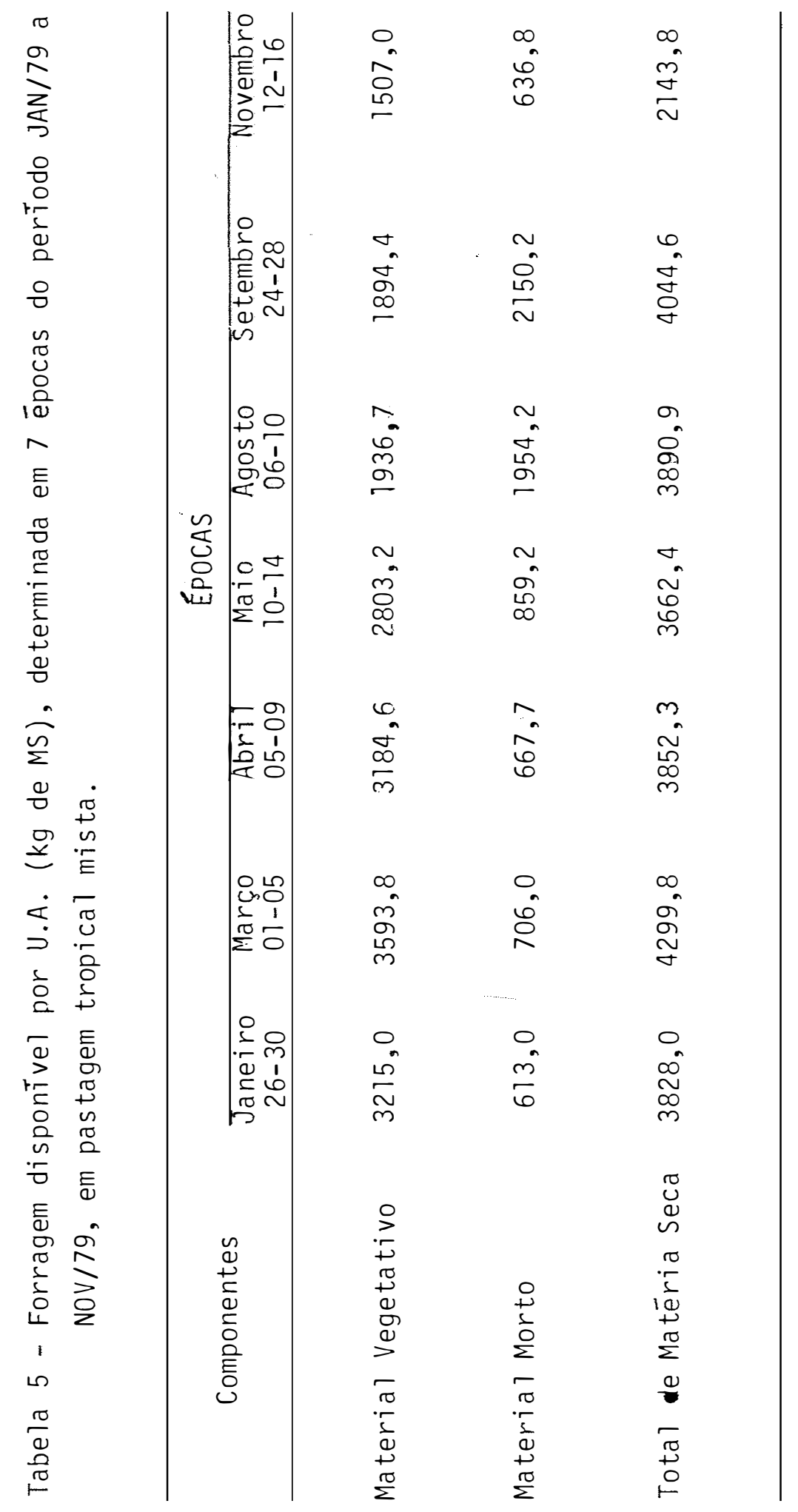




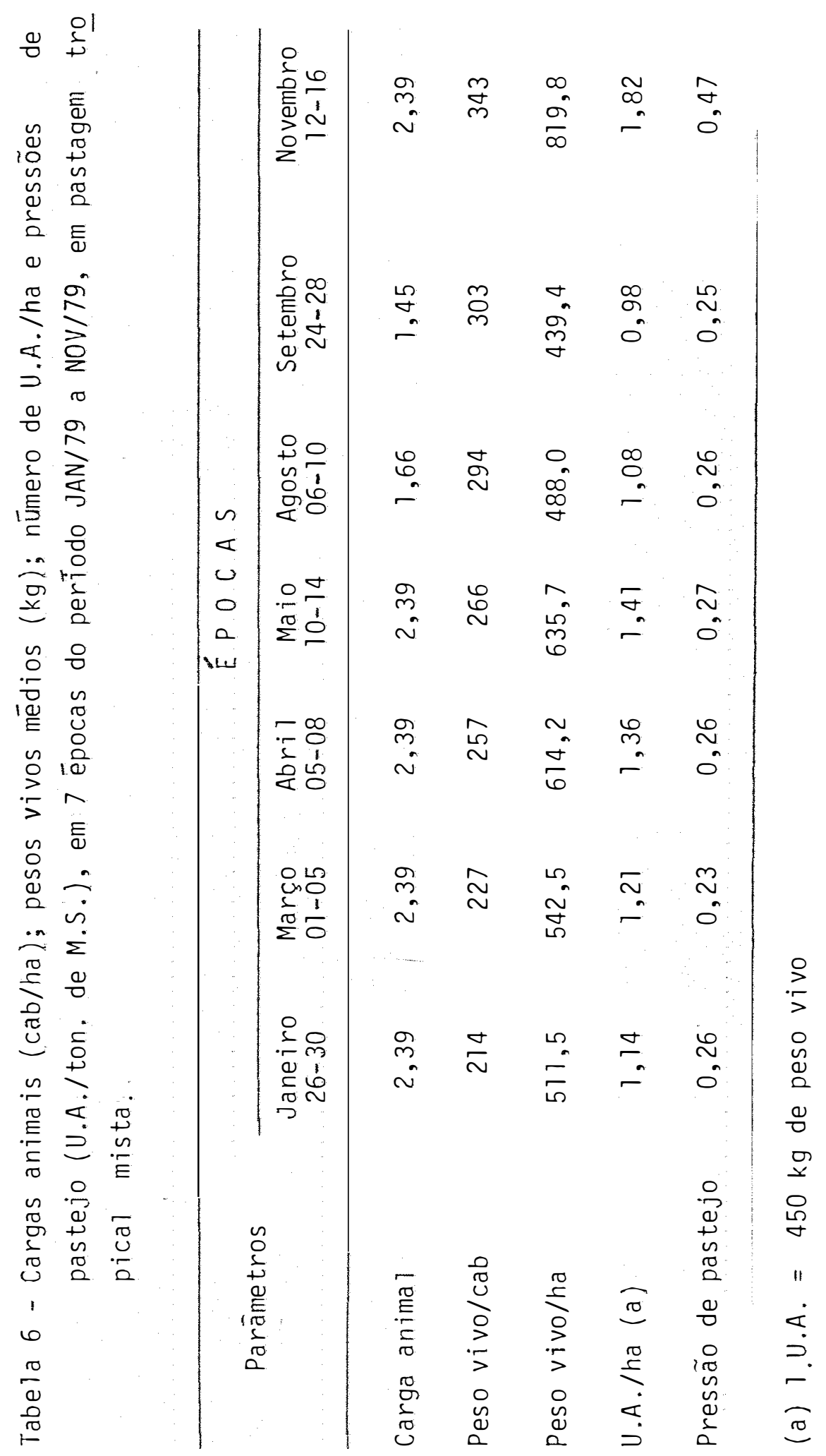




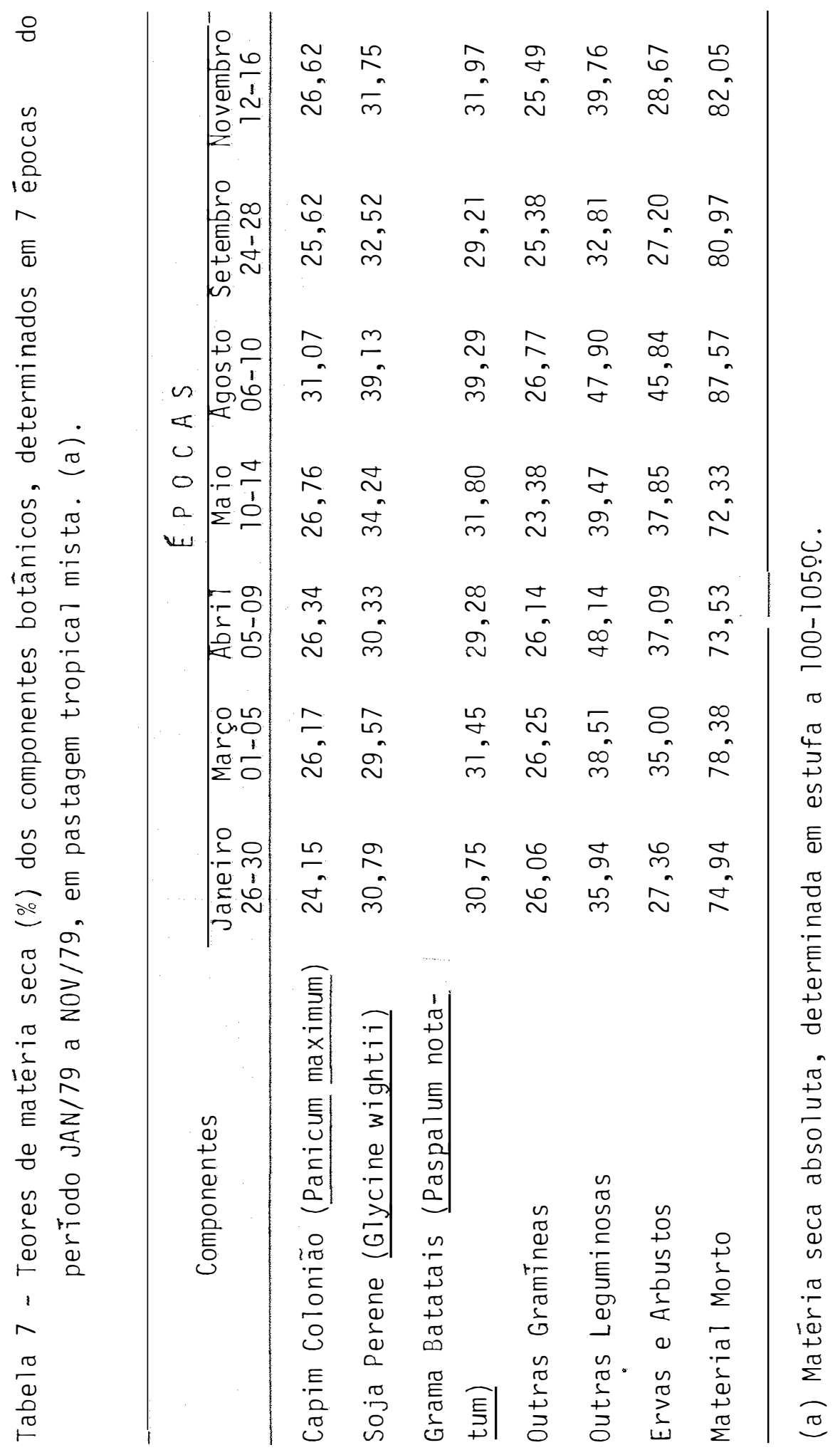


32.

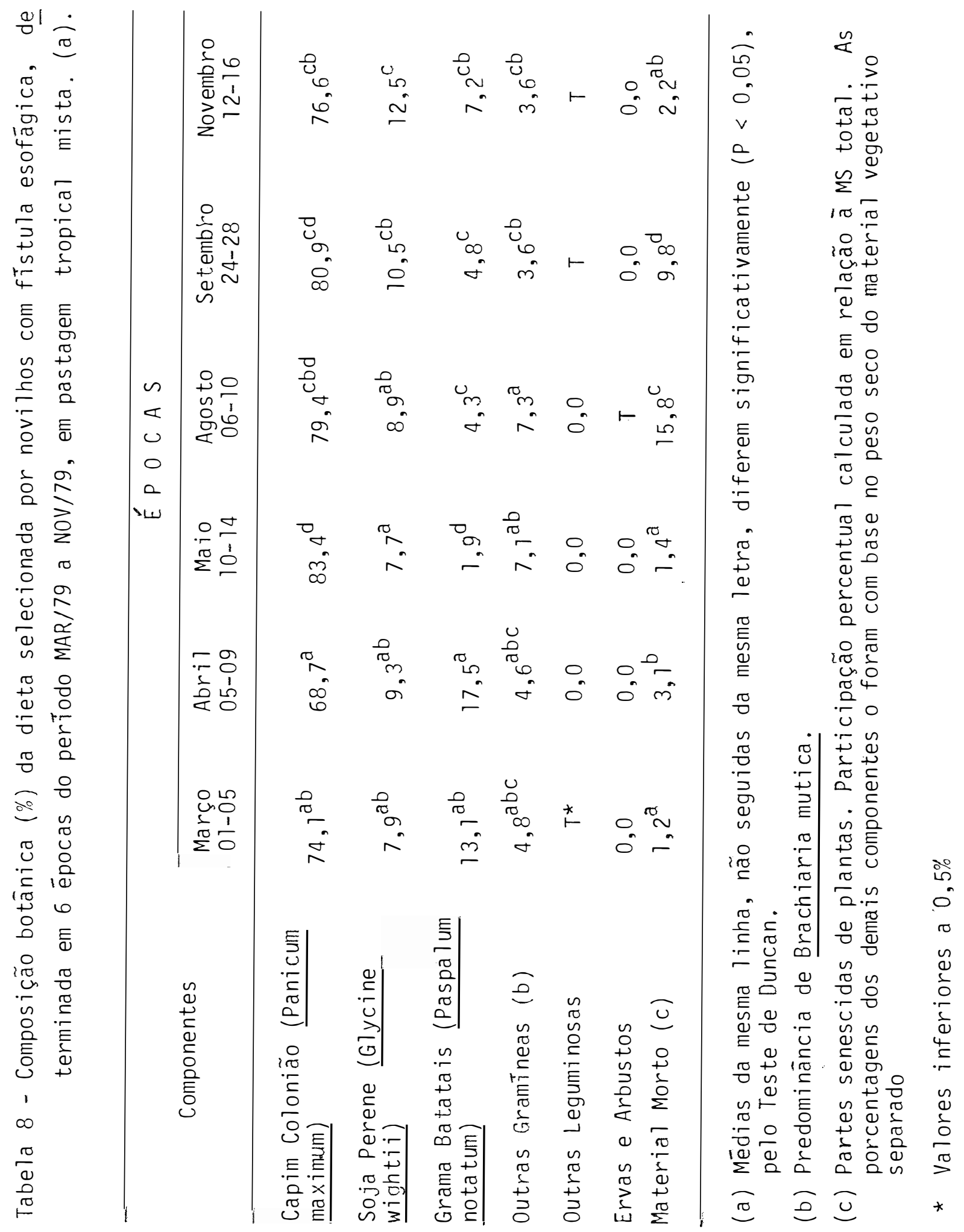



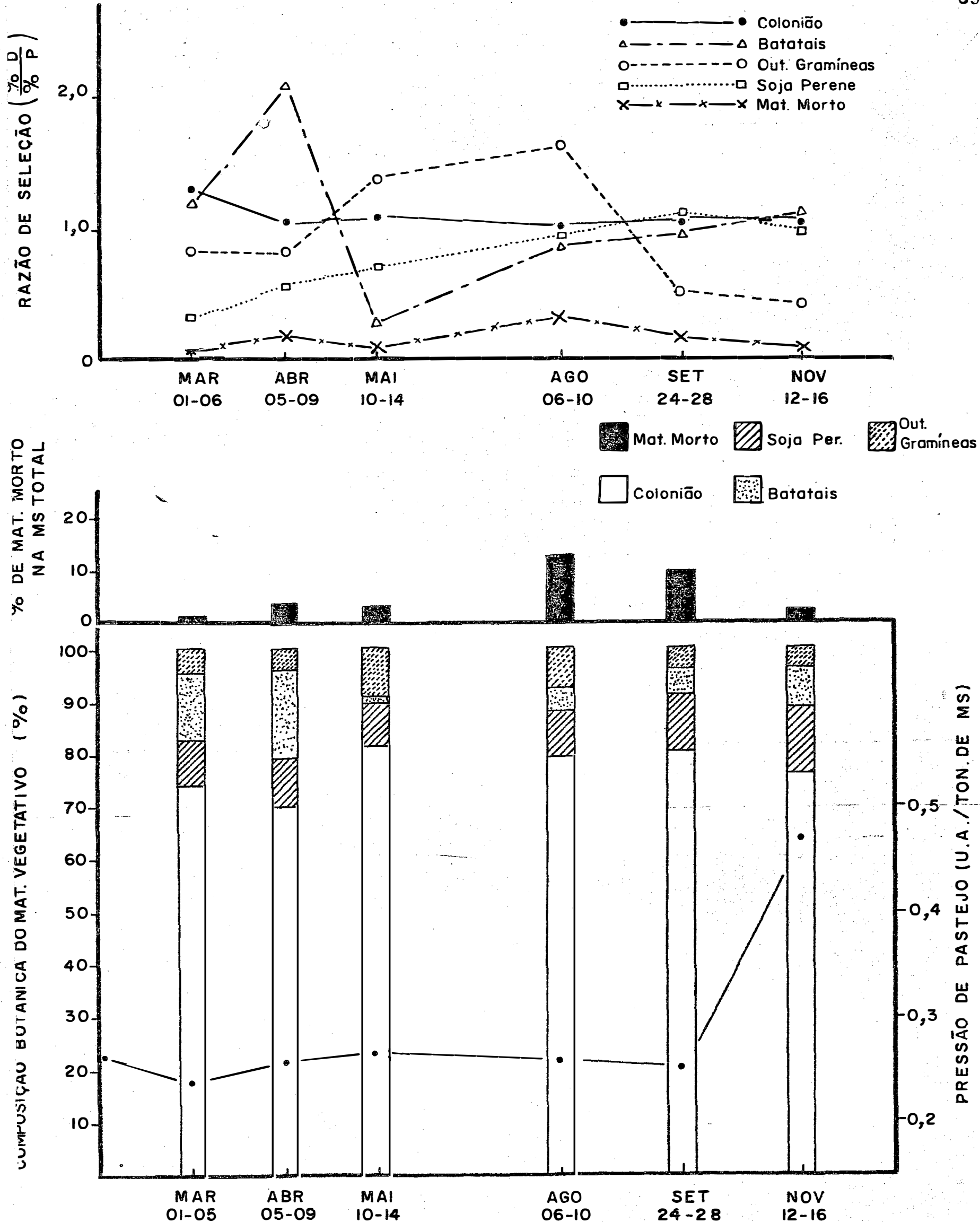

Fir. 6 - Composição botānica (\%) da dieta selecionada por noviłhos com fístulas esofánicas, determinada en 6 énocas do nerīodo MAR/79 a NOV/79, em pas tarem tronical mista; nressão de pastejo (U.A./ton. de MS) e razões de seleção dos princinais componentes da dicta. 


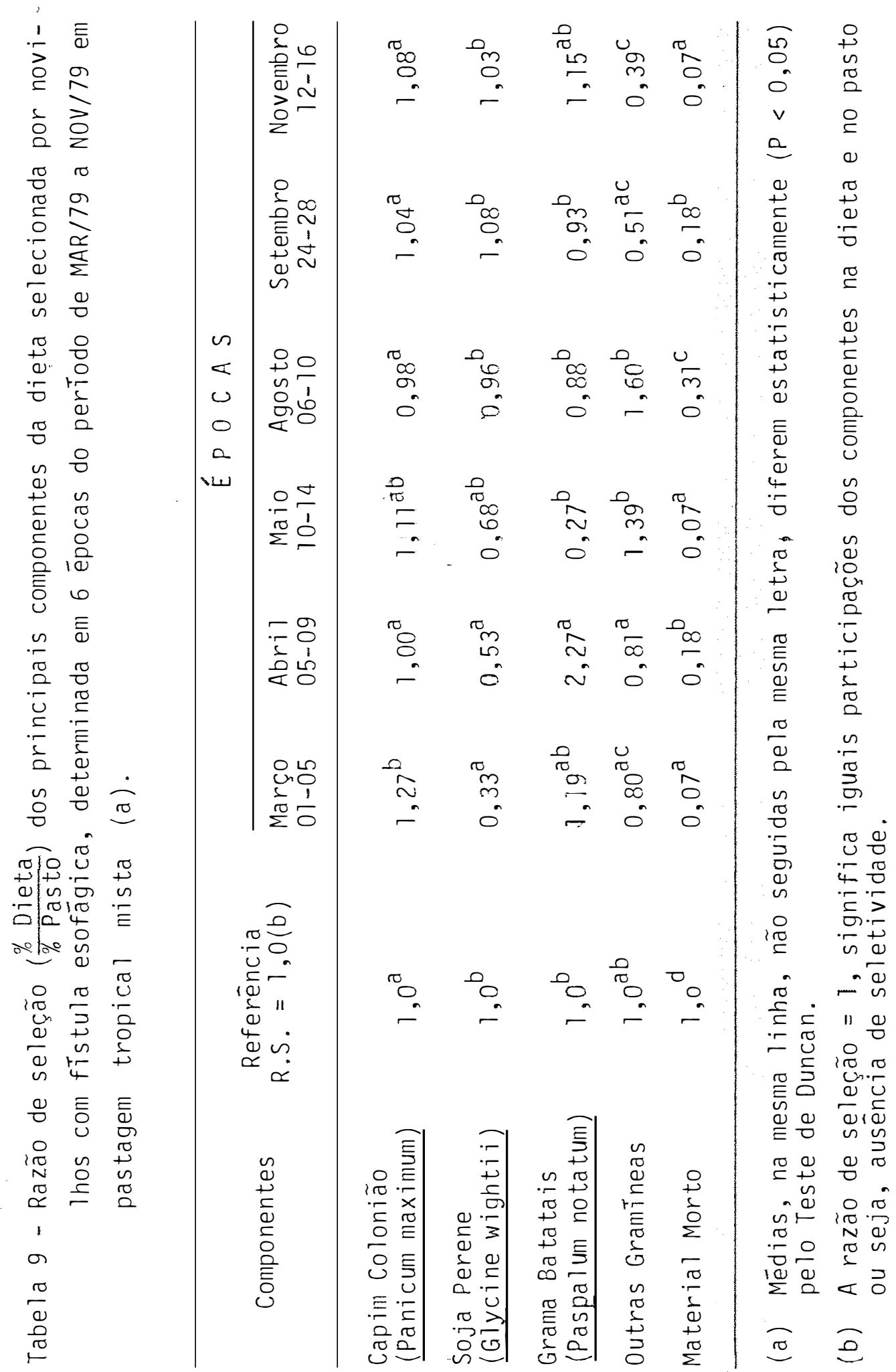


nea, somente em março. A ausēncia de seletividade para o Colonião a partir de abril, pode ser atribuida à remoção progressiva de sua porção folhosa ao Iongo do período de pastejo, como admitem CHACON e STOBBS (1976), embora a dispo nibilidade desse componente continue a aumentar até maio (Tabela 4), provavel mente pelo acūmulo de partes não folhosas (àlongamento do colmo). Em agosto, apesar do Colonião se manter disnonível em quantidade e proporção razoāveis na pastagem (Tabela 4)-considerando a pressão de pastejo imprimida-sua aceita bilidade foi aparentemente a mais baixa do periodo estudado. Nas épocas poste riores, com o início de nova estacào de crescimento, a aceitabilidade desse componente mostrou uma leve tendéncia a aumentar (Tabela 9), mesmo com o considerāvel aumento da pressão de pastejo apōs a amostragem de setembro. Com efeito, como mencionado por aqueles autores, o estado de "folhosidade" parece ter condicionado a aceitabilidade do Colonião durante o perīodo de pastejo es tudado.

Os animais manifestaram uma alta preferéncia pela grama Bata tais en abril, chegando essa espécie a compreender até 17,5\% da forragem inge rida (material vegetativo) nesta ēpoca. Emi maio sua participação na dieta calu abruptamente cara 1,9\%, exnerimentando uma ascenção significativa $(P<$ 0,05) em agosto para uma percentagem maritida em setemuro, tendendo, em novembro, a retornar ao nîvel inicial. Com exceção de abril, em todas as demais épocas as RS não diferiram estatisticamente $(P<0,05)$ da $R S=1,0$, embora entre sí tenham apresentado difierenças consistentes. 0 estádio de desenvolvimen to parece ter influenciado a preferéncia dos animais pela grama Batatais, jä que nos meses em que as condições climáticas propiciaram a rebrota - março, abril e novembro - as RS, embora sen significáncia estatística, aparentemente foram superiores às encontradas nas demais épocas. SIMÃO NETO (7976) tambëm relata altas preferéncias quando a Batatais se encontrava em fase de rebrota. As percentagens de Soja Perene na dieta não variaram até maio, sendo que a partir desta época mostraram uma tendéncia linear crescente descrita pela equação $y^{\prime}=4,76+0,025 x(r=0,97)(P<0,05)$. Quanto à seletividade, os valores de RS correspondentes às amostragens de março e abril fo ram significativamente inferiores a $1,0(P<0,05)$ e às épocas posteriores,as quais não diferiram deste ūitimo valor. Foi encontrada, ainda, uma correlação negativa entre as disponibilidades de forragem verde/UA e as RS referidas ( $r=$ $0,98)(P<0,01)$, cuja tendéncia é descrita pela regressão linear $y=1,658$ $0,000036 x(P<0,07)$ (Fig. 7). Na amostragem de maio foi observada uma alta taxa de ingestão de sementes dessa leguminosa (cerca de 1 semente/9 de MS), 


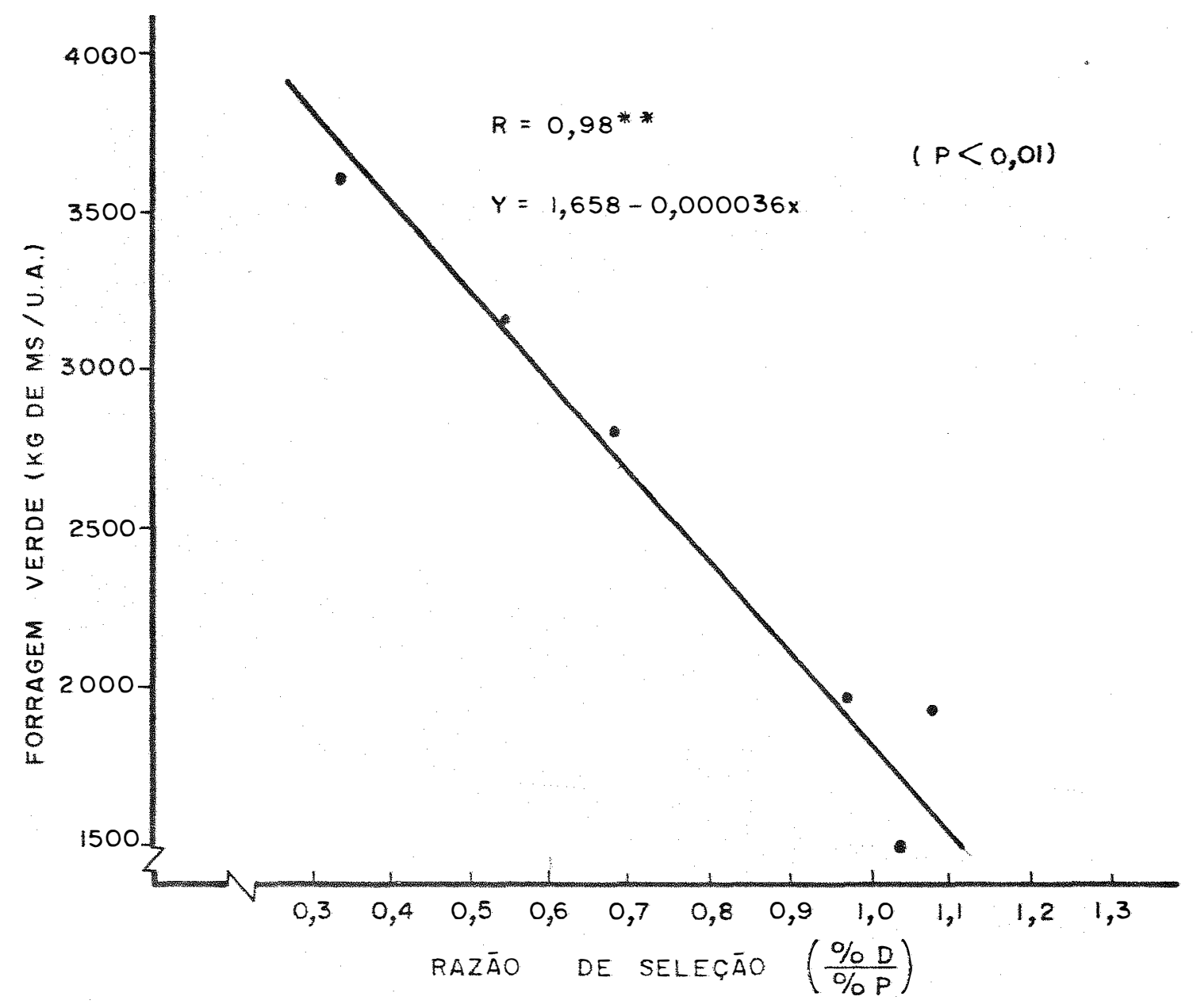

Fig. 7 - Relaçàc entre forrager vegetativa disonnivel (kg de MS/U.h.) e seletividade de soja nerene. (DS). 
as quais apareciam germinadas nas dejeções dos animais em grandes quantidades (até 150 piàntulas/dejeção).

Esses resultados encontrados para a Soja Perene indicam que seu consumo relativo aumentou linearmente a partir de maio, aparentemente quando se acentuou a queda na oferta de forragem verde por U.A. ou, em outras palavras, quuando a pressão de pastejo sobre a forragem verde se acelerou. Nos meses de março a abril, quando houve uma maior disponibilidade desse material, os animais rejeitaram essa leguminosa, rejeição essa que foi restringida progressivamente a nartir de maio, por força da diminuição da forragem disponīvel, principalmente do material vệetativo. A rejeição da So ja em março (verão) e abril concorda parcialmente com a assertiva de que as leguminosas tropicais são menos palatāveis que as gramineas tropicais na primavera e verão (STOBBS, 1375). A auséncia de seietividade no sentido dessa leguminosa confirma, em parte, a observação de KALIL (1977), quando afirma que, em pastagens de certas gramineas e Soja Perene, o animal dá preferēn cia à graminea. De outro 1ado, STOBBS (1977), encontrou para o Siratro rejej ção na primavera e verão e alta aceitabilidade no outono. Em parte do veräo (março), a Soja revelou aceitabilidade semelhante, entretanto, apesar de sua aceitação ter melhorado no outono e inverno, não chẹou a ser selecionada co mo foi o Siratro no outono (STOBBS, 1977). Ainda, segundo esse autor, quando a pressão de pastejo na primavera foi pesada, a proporção da leguminosa na dieta foi semelhante à da pastagem, tal como constatado neste trabalho.

Nas quatro primeiras épocas (março, abril, maio e agosto), o componente Outras Gramineas (predominantemente Brachiaria mutica) teve uma particinação na dieta significativamente superior $(P<0,05)$ às das épocas posteriores (setembro e novembro). As RS desse componente, referentes às épo cas de março e abril, não diferiram estatisticamente da $R S=1,0(P<0,05)$. Em maio e. agosto, os valores de RS também não diferiram de 1,0 porém foram significantemente superiores $(P<0,05)$ àquelas encontradas nas duas épocas anteriores, indicando um aumento da aceitação desse componente. Em setembro houve um declínio consistente $(P<0,05)$ na aceitacão em relação ao més ante rior, porém a RS correspondente não foi estatisticamente inferior a 1,0. Em novembro esse componente apresentou uma rejeição significativa por parte dos animais $(P<0,05)$. 
Embora não se tenha feito mensurações da estrutura da vege tação e discriminado a composição botānica da dieta em termos de partes de plantas, notou-se uma maior ingestão de colmos com a progressão do pas tejo no tempo, associada à defoliação gradual da pastagem. Como, segundo CHACON e STOBBS(1976) e LOURENÇO et alii(1979), esse material tem uma aceitação inferior, è provāvel que, por isso, o componente Outras Gramíneas tivesse sido menos consumido quando a oferta de forragem verde aumentou.

A proporção de Material Morto na dieta, embora inicialmente pequena, aumentou significativamente em abril $(P<0,05)$, retornando, em maio, ao mesmo nível. Em agosto o acréscimo ocorrido nessa proporção foi bastante acentuado, chegando a compreender $16 \%$ do total de MS ingerida, tendo havido um declínio também significativo em setembro e um retorno, em novembro, a nível similar aos encontrados nas trés primeiras épocas.

Embora o Material Morto tivesse sido evitado pelos animais em todas as épocas - todas as RS diferiram estatisticamente de $1,0, \quad(P<$ 0,05) - foi constatada uma variação no grau de rejeição desse componente com o transcorrer do tempo. Assim, o grau de rejeição foi significativa mente maior $(P<0,05)$ em março, maio e novembro - não havendo diferença entre essas épocas - intermediārio em abril e setembro - diferentes das de mais mas não entre si - e menor em agosto.

ARNOLD (1970) relata que, quando hā abundāncia de forra gem, o animal pode exercer livremente suas preferéncias, entretanto quando o suprimento dessa forragem decresce, ele é forçado a ingerir material menos aceitāvel, sob a pena de passar fome, CHACON e STOBBS (1976) confirmam essa assertiva, afirmando que, no outono, o material morto compreendeu $8 \%$ da dieta, enquanto na primavera e verão a proporção desse ma terial foi neglīgívei. Concordantes também foram os resultados obtidos por LOURENÇO et alii (1979), em que a ingestäo de material seco foi maior no período "seco" e nas lotações mais pesadas (maiores pressões de pastejo). Da mesma forma, os resultados deste trabalho indicam que nas épocas em que houve maior oferta de forragem, sobretudo material verde, os animais evitaram a ingestão do material morto, contudo, quando essa oferta decresceu, o consumo desse componente aumentou, possivelmente para 
atender as necessidades de MS do animal. Por outro lado, é provāvel que a disposição desse material na estrutura da vegetação tenha dificultado a sua rejeição por parte dos animais, como lembra HODGSON (1979).

A participação dos componentes Outras Leguminosas e Ervas/ Arbustos, foi negligĩvel, em todas as ēpocas estudadas.

As anālises das variāncias efetuadas (apēndice $A$ ) revelaram diferenças significativas entre animais, quanto à ingestão relativa de Colonião $(P<0,01)$, Soja Perene $(P<0,05)$, Batatais $(P<0,05)$ e Mate rial Morto $(P<0,05)$, o mesmo não se verificando com o componente Outras Gramíneas.

Por outro lado, não se constatou, pelas referidas anāi ses, diferenças estatísticas entre dias na composição botánica da dieta. Houve contudo, significāncia para a interação animais X épocas, com relação aos componentes Colonião, Soja e Batatais, indicando que os animais não apresentaram a mesma tendēncia na ingestão desses componentes ao passar das ēpocas.

SIMAOO NETO (1976), contrariamente a esses resultados, não encontrou diferenças entre animais, para a maioria dos componentes botāni cos da dieta, obtendo, entretanto, diferenças entre dias de amostragem. Por outro lado MINSON et alii (1976) afirmam que as mensurações feitas usualmente indicam considerāvel variação no comportamento alimentar de ani mais no mesmo pasto. ARNOLD et alii (1966), por exemplo, encontraram grandes variações entre carneiros em pastagens temperadas mistas, embora bovinos e ovinos difiram na seletividade de suas dietas (ARNOLD, 1970). Ainda, o prōprio SIMAO NETO (1976) relata que diferenças entre dias de co leta (para bovinos) não foram encontradas por VAN DYNE e HEADY (1965) OS quais acharam, de outro lado, uma certa consistência dos animais em sua seletividade.

5.2.1. - Calibração do método de separação botānica do material ingerido.

Os coeficientes de correlação encontrados entre os valores reais das proporções dos principais componentes da dieta (base peso ver- 
de) e os valores estimados das proporções desses componentes (base peso seco), apōs separação na lupa, encontram-se na Tabela 10.

Tabela 10 - Coeficientes de correlação entre valores reais e estimados das proporções dos principais componentes da dieta.

\begin{tabular}{llc}
\hline \multirow{2}{*}{ Componentes } & \multicolumn{2}{l}{ Coeficiente de Correlação $(R)$} \\
\cline { 2 - 3 } & \multicolumn{1}{c}{ Estimador I } & Estimador II \\
\hline Colonião & $0,97^{\star \star}(\mathrm{a})$ & $0,99^{\star \star}$ \\
Soja Perene & $0,99^{\star \star}$ & $0,99^{\star \star}$ \\
Batatais & $0,95^{\star}(\mathrm{b})$ & $0,97^{\star \star}$ \\
Outras Gramĩneas & $0,83^{\mathrm{ns}}(\mathrm{c})$ & $0,77^{\mathrm{ns}}$ \\
\hline
\end{tabular}

(a) $* \star(P<0,01)$

(b) $*(P<0,05)$

(c) ns (não significativo)

Esses resultados permitem concluir que a eficiēncia do método utilizado na separação botānica foi satisfatória, com exceção do com ponente Outras Gramīneas, cujo reconhecimento à lupa foi dificultado pela semelhança com o capim Colonião; embora para cálculo dessas correlações tenham sido computadas apenas 4 pares de variāveis, correspondentes às quatro primeiras épocas amostradas.

\section{3. - Comportamento dos Animais Fistulados.}

Como pode ser observado na Tabela 6 e na Figura 5, os animais apresentaram um desenvolvimento ponderal satisfatório ao longo do pe riodo experimental, o que constitui um indicador do comportamento geral desses animais.

0 ganho de peso diārio médio foi de $445 \mathrm{~g} / \mathrm{cab} .$, com ganhos de a té 822-857 g nos meses de abril e novembro; comparáveis aos de animais não fistulados em pastagens tropicais cultivadas (500-600 g) como ci ta HUMPREYS (1978). Essa performance poderia ter sido superior, se não considerados os ganhos do primeiro més, em que ainda se processava a 
adaptação dos animais, e a queda acentuada do ganho de peso em maio, por efeito da quebra e perda de cānulas, com os efeitos estressantes que isso acarretou, tal como relatado em Material e Métodos.

Embora fossem utilizados cinco animais efetivos para a amostragem da dieta, apenas quatro destes foram considerados para mensura ção do desenvolvimento ponderal. O quinto animal efetivo, por ter ficado com uma fístula demasiada aberta, não apresentou um desempenho que pudesse ser considerado representativo. Esse animal apresentou continuamente perdas excessivas desaliva. e material regurgitado, extravasado pela fístu 1a, tendo, ainda, em duas ocasiões, perdido a cānula, o que agravou seu estado geral.

Com relação aos dois animais de reserva, um deles demons trou, desde a fase pós-operatória, baixa aptidão para esse tipo de trabá1ho, devido ao seu temperamento excessivamente nervoso o que o tornou pro gressivamente incoveniente ao ponto de se tornar necessāria sua retirada do ensaio. O outro, em virtude de problemas havidos na fase operatōria e pōs-operatōria, apresentou na maior parte do tempo ulcerações crōnicas, apesar dos cuidados terapéuticos dispensados, o que resultou em comportamento extremamente arredio ao manejo.

A tendēncia de fechamento das fístulas, como mencionam alguns autores (BREDON e SHORT, 1977 e MINSON et alii, 1976), foi observada em cinco dos animais. Nos casos em que as perdas de cánulas provocaram um estreitamento mais pronunciado das fístulas, utilizou-se rolhas ("plugs") de diāmetro menor, substituidas posteriormente pelas usuais, tal como recomendado por esses A.A., com resultados positivos.

0 uso de "buchas" de espuma de borracha, inseridas na parte posterior do esōfago, conforme sugerido por MINSON et alii (1976), aumentou consideravelmente o tamanho das amostras da dieta.

A técnica de proceder as amostragens da dieta nas horas do dia em que os animais revelam tendéncia para pastarem (MINSON et alii, 1976), pareceu ser eficiènte, não sō por minimizar as interferéncias no comportamento seletivo, como tambëm por ter resultado em poucos casos de regurgitação durante os períodos de coleta. 


\section{CONCLUSÕES}

Não obstante a ocorréncia de fatores atīpicos (geadas è pragas), condicionando parte das respostas obtidas neste estudo, é possivel concluir que:

1) Ocorreram variações estacionais na disponibilidade de forragen como um todo e, diferenciadamente, em seus componentes botānicos, notadamente no material venetativo, severamente reduzido no inverno, em oposição ao material morto, o qual atingiu mais da metade da matéria seca presente no pasto.

2) A redução diferenciada nos diversos componentes da forragem verde (material vegetativo), decorrente dos fatores climáticos, somados aos efeitos do ataque de lagartas e da pressão de pastejo, principalmente daquela imprimida no início da fase de rebrota da pastagem, levou a uma menor oferta e participação da Soja Perene na forragem disponível ao final do ensaror."

3) Em março e abril, quando houve uma maior disponibilidade de forragem verde, os animais tiveram oportunidade de selecionar suas dietas, manifestando rejeição pela Soja Perene. Nas épocas posteriores a seletividade foi restringida, inicialmente pela baixa disponibilidade de forragem verde no inverno; acentuada pela maior pressão de pastejo imposta na primavera (início da rebrota). O consumo relativo da leguminosa, i- 
nicialmente constante, apresentou uma tendéncia linear crescente a partir de maio quando se acentuou o declînio da forragem verde disponivel por $U$. A.. Sua aceitabilidade melhorou progressivamente com a diminuição da dispo nibilidade desse material para os animais.

4) 0 Colonião foi selecionado apenas em março. Nas demais épocas, provavelmente nela progressiva remoção de sua porção folhosa, o consumo relativo desse componente não diferiu de suas proporções na pasta gem. De outro lado, a grama Batatais demonstrou ser mais palatável na fase de rebrota, chegando a coniribuir, em abri1, com $36 \%$ da forragem verde ingerida. 0 componente Dutras Gramineas teve maior participação na dieta durante o inverno.

5) Nas anāilises da variāncia efetuadas, foram encontradas diferenc:as significantes entre animais na composição botānica da dieta, o que não ocorreu entre dias de amostraçem. A interação animais $x$ épocas foi consistente para o consumo relativo de Colonião, Soja e Batatais, indicando que, embora os animais consumissem diferentes proporções desses componentes, não mostraram tendéncias semelhantes ao longo do tempo. Isso pode sugerir que experimentos dessa natureza devam ser mais longos ou com maior número de animais.

6) 0 desempenho animal foi satisfatōrio, ạnresentando uma tendéncia crescente em peso vivo, em todo o período experimental, com ganhos mais pronunciados nas épocas em que houve maior disponibilidade de forragem verde. Essa performance, comparāvel à de animais não fistulados em pastagens tropicais cultivadas, atesta a viabilidade do uso de bovinos com fístula esofágica em ensaios de pastejo.

Assim, como. uma primeira aproximação, é possivel sugerir que o equilíbrio botánico de uma ṇastagem tropical mista pode ser prejudi cado quando, em seu manejo, a seletividade de pastejo é restringida, sobretudo na fase inicial da estação de crescimento. 
7. SUMIIARY

The seasonal selectivity of grazing cattle was investigated in a grass/legume tropical pasture at the Department of Animal Husbandry/ ESALQ, in the State of São Paulo. The purpose of this work was to determine the botanical composition of the forage on offer and of the forage selected by esophageal fistulated steers, during seven times within the period Jan/79 - Nov/79.

The pasture was composed of Panicum maximum, Glycine wightii, Paspalum notatum and other grasses. Their proportions, in terms of dryweight of the green forage on offer, varied respectively from 54 to $80 \%, 25$ to $9 \%, 14$ to $5 \%$, and 6 to $9 \%$, during the experimental period. The forage on offer and its botanical composition were estimated by cutting 1,0 $1,0 \mathrm{~m}$ quadrats at 20 fixed plots in the pasture.

The total dry matter in the pasture had some seasonal variation. The green forage was the component which presented the widest range of variations under differents climate and grazing pressures. The occurrence of frost in the Fall decreased substantialy the components of green forage on offer during the Hinter, and Glycine was the component that decreased the most. Inversaly, the dead material was responsible to more than half of the total dry matter in the pasture, during the Fall.

The associated effects of climate (including frost), the attack of "caterpillar", and the high grazing pressure imposed at the beginning of the growth season (Spring) led to a shortage of the available Glycine in the pasture and its proportion decreased at the end of the experi ment. 
The botanical composition of the diet was estimated by manual separation of extrusa samples with the aid of a binocular microscope. The extrusa samples were collected from five esophageal fistulated steers after 30-40 minutes of grazing during four consecutive days in each sampling period.

During March and April, when the green forage on offer .. was high, the animals selected their diets refusing the Glycine. On the later seasons this selection was restricted by the low availability of green forage on offer. Also, this lack of selectivity was accentuated by the high grazing pressure during the Spring . The relative intake of Glycine did not vary at first, but increased linearly from May on, when the green forage on offer/animal unity decreased sharply. Its acceptability improved progressively when the green forage on offer decreased.

The Panicum maximum was selected only in March. After that, the proportions of this grass in the diet did not differ from its proportions in the pasture, probabily because the progressive defoliation by grazing.

The Paspalum notatum showed a good nalatability when regrowth conditions were favorable. Under these conditions Paspalum made up $16 \%$ of the green material ingested in Anril. The component "Other Grasses" was consumed at a higher rate during the linter, compared to Summer' and 'Fall periods.

There were differences among animals, considering the botanical composition of the diet, but the animals had a similar diet in different sampling days. The animal performance was similar to that of unfistulated animals indicating the potential of these animals to evaluate grazing trials.

Considering the atypical factors(occurrence of frost and "caterpillar" attack), it is possible to suggest that the balance in the botanical components of a grass/legume tropical pasture may be damaged through a grazing management that does not permit animal's selectivity, mainly at the beginning of the growth season. 
ALDER, F. E., 1969. The use of cattle with oesophegeal fistulae in gras land experiments. Journal of the British Grassland Society, Hurley, 24: $6-13$.

ANDERSON, V. L. e McLEAN, R. A., 1974. Design of Experiments. New York, Marcel Dekker. 418p.

ARNOLD, G.W.; BALL, J.; McMANUS, W. R. e BUSH, I. G., 1966. Studies on the diet of the grazing animal. I. Seasonal changes in the diet of sheep grazing on pastures of different availability and composition. Australian Journal of Agricultural Research, East Melbourne, 17: 543 56.

ARNOLD, G.W., 1970. Regulation of Food Intake in Grazing Ruminants. In: Physiology of Digestion and Metabolism in the Ruminant. Ed. A. T. Phillipson Oriel Press Ltd.. Newcastle, England. p. 264-276.

BISHOP, J. P. e FROSETH, J. A., 1970. Improved techniques in esophageal fistulation of sheep. American Journal of Veterinary Research, Chicago 31: 1505-7. 
BRREDON, R. M. e SHORT, A. M., 1971. Oesophageal fistulation of cattle for pasture utilization studies, post-fistulation care and use of animals and sampling procedures. Agroanimalia, Landbouwet, 3: 141-4.

CHACON, E. e STOBBS, T. H., 1976. Influence of Progressive defoliation of a Grass Sward on the Eating Behaviour of Cattle. Australian Journal of Agricultural Research, East Melbourne, 27: 709-27.

COOPER, J.P. e TAINTON, N. M., 1968. Light and temperature requirements for the growth of tropical and temperate grasses. Herbage Abstracts, Hurley, 38: 167-76.

DEMATTÉ, J. L., 1980. Comunicação pessoal. Escola Superior de Agricultura "Luiz de Queiroz", Piracicaba, S.P.

FREE, J. C.; SIMS, P. L. e HANSEN, R. M., 1971. Methods of estimating dry-weight composition in diets os steers. Journal of Animal Science, Albany, 32: 1003-7.

HODGSON, J., 1979. Nomenclature and definitions in grazing studies. Grass and Forage Science, Hurley, 34: 11-18.

HUMPHREYS, L. R., 1978. Tropical Pastures and Fooder Croops. London, Longman Group Limited, 135p.

JONES, R. J.; LUDLOW, M. M.; TROUGTON, J. H. e BLUNT, C. G., 1979. Estimation of the proportion of $C_{3}$ and $C_{4}$ plant species in the diet of animais from the ratio of natural $12 \mathrm{C}$ and $13 \mathrm{C}$ isotopes in the faces. Journal of Agricultural Science, Cambridge, 92: 91-100.

KALIL, E. B., 1977. Princípios de Técnica Experimental com Animais. Piracicaba, 210p. 
LOURENÇO, A. J.; ESCUDER, C. J. e RODRIGUEZ, N. M., 1979. Efei to de diferentes lotações em pastagens de Brachiaria decumbens Stapf. III. Dieta selecionada. Anais da XVI Reunião Anual da S.B.Z., Curitiba, pp. 238.

LOURENÇO, A. J.; ESCUDER, C. J. e RODRIGUES, N. M., 1979. Efei to de dife rentes lotações em pastagens de Brachiaria decumbens Stapf. IV. Comparação entre forragem disponível e dieta selecionada. In: Anais da XVI Reunião Anual da Sociedade Brasileira de Zootecnia, Curitiba, p. 239.

LUDLOW, M. M. e WILSON, G. L., 1970. Studies on the productivity of tropical pasture plants. II Growth analysis, photosynthesis, and respiration of 20 species of grasses and legumes in a controlled enviroment Australian Journal of Agricultural Research, East Melbourne, 21: 18394 .

LUDLOW, M. M. e WILSON, G. L., 1971. Photosynthesis of tropical pasture plants. I. Illuminance, carbon dioxide concentration, leaf temperature and leaf-air-vapour pressure difference. Australian Journal of Biological Science, East Melbourne, 24: 449-70.

MINSON, D. J. e MILFORD, R., 1967. Intake and crude protein content of mature Digitaria decumbens and Medicago sativa.......Aus.tralian Journal of Experimental Agriculture and Animal Husbandry, East Melbourne, 7: 546.

MINSON, D. J.; STOBBS, T. H.; HEGARTY, M. P. e PLAYNE, M. J., 1976. Measuring the nutritive value of pasture plants. In: SHAW, N. H. e BRYAN, W. W. Tropical Pasture Research, Hurley, Commonwealth Agricultural Bureaux, p. 308-338.

NORRIS, D. 0., 1972. Leguminous plants in tropical pastures. Tropical Grasslands, Brisbane, 6: 159-70. 
PEDREIRA, J. V., 1973. Crescimento estacional dos capins Colonião (Panicum maximum Jacq.), Gordura (Mellinis minutiflora, Pal. de Beauv.), Jä raguá (Hyparrenia rufa, Stapf.) e Pangola de Taiwan A-24 (Digitaria pentizii, Stent). Boletim da Industria Animal, Nova Odessa, 30: 59152.

PEDREIRA, J. V., 1973. Crescimento estacional de leguminosas forrageiras. Revista da Sociedade Brasileira de Zootecnia, Viçosa, 2: 27-33.

ROBERTS, C. R., 1979. Some common causes of failure of tropical legume/ grass pastures on commercial farms and suggested remedies. In: TERGAS, L. E. e SANCHEZ, P. A. Pasture Production in Acids Soils of the Tropics. Seminar. Cali, Colombia, 339-416.

SIMARO NETO, M. S., 1976. Composição botānica e qualidade da dieta selecio nada em pastagem nativa por novilhos azebuados com fístula esofágica. II. Período de setembro a fevereiro de 1976. Tese apresentada à Escola de Veterināria da Universidade Federal de Minas Gerais. Belo Horizonte, $62 p$.

SLATER, J. e JONES, R. J., 1971. Estimation of the diets selected by grazing animals from microscopic analysis of the faeces - a warming. Journal of Australian Institute of Agricultural Science, Albert Park, 37: $238-40$.

SNEDECOR, G. W. e COCHRAN, W. G., 1975. Métodos Estadisticos. 3a. ed. Me xico, Conpañia Editorial Continental, S.A., 203p.

STOBBS, T. H., 1975. Factors limiting the nutricional value of grazed tro pical pastures for beef and milk production. Tropical Grasslands, Bris bane, 9: 141-50. 
STOBBS, T. H., 1977. Seasonal changes in the preference by cattle for Macroptilium atropurpureum cv. Siratro. Tropical Grasslands, Brisbane, 11: 87-91.

TADMOR, N. H.; BRIEGHET, A.; NOYMEIR, I.; BENJAMIM, R. W. e EYAL, E., 1975. An evaluation of the Calibrated Weight-Estimate Method for Measuring Production in Annual Vegetation. Journal of Range Management, Denver, 28: 65-9.

't MANNETJE, L.; JONES, R. J. e STOBBS, T. H., 1976. Pasture evaluation by grazing experiments. In: SHAW, N. H. e BRYAN, W. W. Tropical Pasture Research. Hurley, Commonwealth Agricultural Bureaux, p. 194-234.

TOTHILL, J. C., 1978. Measuring Botanical Composition of Grasslands. In: 't MANNETJE, L. Heasurement of Grassland Vegetation and Animal Production. Hurley, Commonwealth Agricultural Bureaux, p. 22-62.

VAN DYNE, G. M. e TORELL, D: T., 1964. Development and Use of the Esopha geal Fistula: A review. Journal of Range Management, Denver, 17:7-19.

VAVRA, M.; RICE, R. W. e HANSEN, R. M., 1978. A comparison of Esophageal Fistula and Fecal Material to Determine Steer Diets. Journal of Range. Management, Denver, 31: 11-13.

VILLA NOVA, N. A., 1980. Comunicação pessoal. Escola Superior de Agricul tura "Luiz de Queiroz", Piracicaba, S. P. 
ANALISES DE VARIÂNCIA DOS RESULTADOS

1 - Percentagens dos componentes botānicos na dieta:

1.1. - Colonião

\begin{tabular}{|c|c|c|c|}
\hline Fonte de Variação & GL & QM & $\mathrm{F}$ \\
\hline Epocas & 5 & 122,29 & $6,65^{\star *}$ \\
\hline Animais & 4 & 182,17 & $9,91 * \star$ \\
\hline Animais X Epocas & 20 & 76,63 & $4,16 * *$ \\
\hline Dias & 1 & 42,99 & $2,33^{\mathrm{ns}}$ \\
\hline Erro & 29 & 18,38 & \\
\hline Tctal & 59 & & \\
\hline \multicolumn{4}{|c|}{$\begin{aligned} & \star *=\text { altamente significativo }(P<0,01) \\
& *=\text { significativo }(P<0,05) \\
& \text { ns }=\text { não significativo } \\
& \text { Coeficiente de Variação }(C V)=7 \%\end{aligned}$} \\
\hline
\end{tabular}

1.2. - Soja Perene

Fonte de Variação

\begin{tabular}{rcc} 
GL & QM & F \\
\hline 5 & 36,56 & $4,65^{\star \star}$ \\
4 & 37,53 & $4,77^{\star \star}$ \\
20 & 25,59 & $3,26^{\star \star}$ \\
1 & 13,29 & $1,69^{\text {ns }}$ \\
29 & 7,86 &
\end{tabular}

Total 59

$\mathrm{CV}=16 \%$ 
1.3. - Batatais

\begin{tabular}{lrrc} 
Fonte de Variação & $G L$ & QM & $F$ \\
\hline Epocas & 5 & 407,33 & $11,65^{\star \star}$ \\
Animais & 4 & 107,32 & $3,07^{\star}$ \\
Animais X Epocas & 20 & 87,94 & $2,82^{\star}$ \\
Dias & 1 & 28,54 & $0,82^{\text {ns }}$ \\
Erro & 29 & 34,96 & \\
\hline
\end{tabular}

Tota]

59

$C V=42 \%$

1.4. - Outras Gramineas

\begin{tabular}{lrrr} 
Fonte de Variação & GL & QM & $F$ \\
\hline Epocas & 5 & 40,22 & $2,76^{\star}$ \\
Animais & 4 & 18,03 & $1,24^{\mathrm{ns}}$ \\
Animais X Epocas & 20 & 13,08 & $0,80^{\mathrm{ns}}$ \\
Dias & 1 & 10,17 & $0,70^{\mathrm{ns}}$ \\
Erro & 29 & 14,57 & \\
& & & \\
\hline
\end{tabular}

Total

59

$C V=30 \%$ 
1.5. - Material Morto

$\begin{array}{lrrr}\text { Fonte de Variação } & \text { GL } & \text { QM } & F \\ \text { Epocas } & 5 & 532,81 & 43,04 * * \\ \text { Animais } & 4 & 42,50 & 3,43^{*} \\ \text { Animais X Epocas } & 20 & 9,21 & 0,74^{\mathrm{ns}} \\ \text { Dias } & 7 & 21,40 & 1,73^{\mathrm{ns}} \\ \text { Erro } & 29 & 12,38 & \\ & & & \\ \text { Total } & 59 & & \\ \text { CV }=46 \% & & \end{array}$

2. Razões de seleção dos principais componentes da dieta.

2.1. - Colonião

\begin{tabular}{lrrr} 
Fonte de Variação & GL & QM & F \\
\hline Epocas & 5 & 0,05 & $2,72^{*}$ \\
Animais & 4 & 0,05 & $2,24^{\mathrm{ns}}$ \\
Erro & 20 & 0,02 & \\
& & & \\
Total & 29 & & \\
CV $=13 \%$ & & &
\end{tabular}


2.2. - Soja Perene

\begin{tabular}{lrcc} 
Fonte de Variação & GL & QM & F \\
\hline Epocas & 5 & 0,45 & $4,75^{* *}$ \\
Animais & 4 & 0,11 & $1,12^{\text {ns }}$ \\
Erro & 20 & 0,09 & \\
& & & \\
Tota 7 & 29 & & \\
CV $=40 \%$ & & &
\end{tabular}

2.3. - Batatais

$\begin{array}{lrrr}\text { Fonte de Variação } & \text { GL } & \text { QM } & \text { F } \\ \text { Epocas } & 5 & 2,75 & 2,77^{*} \\ \text { Animais } & 4 & 0,97 & 1,25^{\mathrm{ns}} \\ \text { Erro } & 20 & 0,78 & \\ & & & \\ \text { Total } & 29 & & \\ \text { CV }=79 \% & & & \end{array}$

2.4. - Outras Gramīneas

\begin{tabular}{lrcc} 
Fonte de Variação & GL & QM & F \\
\hline Epocas & 5 & 1,15 & $9,12^{\star \star}$ \\
Animais & 4 & 0,27 & $2,12^{\text {ns }}$ \\
Erro & 20 & 0,13 & \\
\hline Total & 29 & & \\
CV $=38 \%$ & & &
\end{tabular}




\section{5. - Material Morto}

\begin{tabular}{lrcc} 
Fonte de Variação & GL & QM & F \\
\hline Epocas & 5 & 0,046 & $12,13^{\star \star}$ \\
Animais & 4 & 0,0104 & $2,74^{\star}$ \\
Erro & 20 & 0,0038 & \\
\hline Total & & & \\
CV $=47 \%$ & 29 & &
\end{tabular}

